\title{
Hurricane Impacts to Tropical and Temperate Forest Landscapes
}

\section{Citation}

Boose, Emery R., David R. Foster, and Marcheterre Fluet. 1994. Hurricane Impacts to Tropical and Temperate Forest Landscapes. Ecological Monographs 64, no. 4: 369-400. Portico. doi:10.2307/2937142.

\section{Published Version}

doi: $10.2307 / 2937142$

\section{Permanent link}

http://nrs.harvard.edu/urn-3:HUL.InstRepos:29394999

\section{Terms of Use}

This article was downloaded from Harvard University's DASH repository, and is made available under the terms and conditions applicable to Other Posted Material, as set forth at http:// nrs.harvard.edu/urn-3:HUL.InstRepos:dash.current.terms-of-use\#LAA

\section{Share Your Story}

The Harvard community has made this article openly available.

Please share how this access benefits you. Submit a story.

Accessibility 


\title{
HURRICANE IMPACTS TO TROPICAL AND TEMPERATE FOREST LANDSCAPES ${ }^{1}$
}

\author{
EMERy R. BOose, DAVID R. Foster, AND MARCheterRe Fluet \\ Harvard Forest, Harvard University, Petersham, Massachusetts 01366 USA
}

\begin{abstract}
Hurricanes represent an important natural disturbance process to tropical and temperate forests in many coastal areas of the world. The complex patterns of damage created in forests by hurricane winds result from the interaction of meteorological, physiographic, and biotic factors on a range of spatial scales. To improve our understanding of these factors and of the role of catastrophic hurricane wind as a disturbance process, we take an integrative approach. A simple meteorological model (HURRECON) utilizes meteorological data to reconstruct wind conditions at specific sites and regional gradients in wind speed and direction during a hurricane. A simple topographic exposure model (EXPOS) utilizes wind direction predicted by HURRECON and a digital elevation map to estimate landscape-level exposure to the strongest winds. Actual damage to forest stands is assessed through analysis of remotely sensed, historical, and field data.

These techniques were used to evaluate the characteristics and impacts of two important hurricanes: Hurricane Hugo (1989) in Puerto Rico and the 1938 New England Hurricane, storms of comparable magnitude in regions that differ greatly in climate, vegetation, physiography, and disturbance regimes. In both cases patterns of damage on a regional scale were found to agree with the predicted distribution of peak wind gust velocities. On a landscape scale there was also good agreement between patterns of forest damage and predicted exposure in the Luquillo Experimental Forest in Puerto Rico and the town of Petersham, Massachusetts. At the Harvard and Pisgah Forests in central New England the average orientation of wind-thrown trees was very close to the predicted peak wind direction, while at Luquillo there was also good agreement, with some apparent modification of wind direction by the mountainous terrain. At Harvard Forest there was evidence that trees more susceptible to windthrow were felled earlier in the storm.

This approach may be used to study the effects of topography on wind direction and the relation of forest damage to wind speed and duration; to establish broad-scale gradients of hurricane frequency, intensity, and wind direction for particular regions; and to determine landscape-level exposure to long-term hurricane disturbance at particular sites.
\end{abstract}

Key words: hurricane; landscape patterns; modeling; natural disturbance; New England (USA); Puerto Rico; regional patterns; spatial scales; temperate forests; topographic exposure; tropical forests; wind damage.

\section{INTRODUCTION}

Historically, hurricanes have been one of the major natural disturbance factors affecting Atlantic coastal areas from northern South America, through the Caribbean and Gulf Coast region, to eastern North America as far north as the Maritime Provinces of Canada (NOAA 1971, Neumann et al. 1987). Hurricanes are a significant geomorphic force that reconfigures shorelines, inflicts substantial property damage, and creates extensive windthrow in forested areas (Gentry 1966, Anthes 1982). Wind damage serves as an important source of landscape-level patterning in forests and is a major factor initiating vegetation dynamics (Naka 1982, Denslow 1985, Foster and Boose 1992). At the ecosystem level, extensive blowdown may be an important factor regulating hydrological, energy, and nutrient regimes (Whigham et al. 1991, Lugo and Scatena 1993). The role that hurricanes play in determining ecosystem

\footnotetext{
${ }^{1}$ Manuscript received 29 January 1993; revised 12 November 1993; accepted 22 November 1993.
}

function and landscape patterns in tropical and temperate regions has made this disturbance process a major focus of research at numerous sites (e.g., Luquillo Experimental Forest, Puerto Rico; North Inlet Marsh, South Carolina; Virginia Coast Reserve, Virginia; Harvard Forest, Massachusetts).

Despite an awareness of the importance of hurricanes, there exists among ecologists only a rudimentary understanding of their meteorological characteristics and an incomplete knowledge of their role in natural forest dynamics (Smith 1946, Webb 1958, Bormann and Likens 1979, Lugo et al. 1983, Boucher et al. 1990, Foster and Boose 1992). What is needed is a more complete understanding of how the hurricane's energy is distributed and how it is expended on ecosystems (Moore 1989, Walker et al. 1991). To understand the long-term disturbance regime for a particular region we must know the storm history and the gradients in storm frequency and intensity for that region. Such information could further other ecological studies in hurricane-prone areas and provide ecosystem connec- 


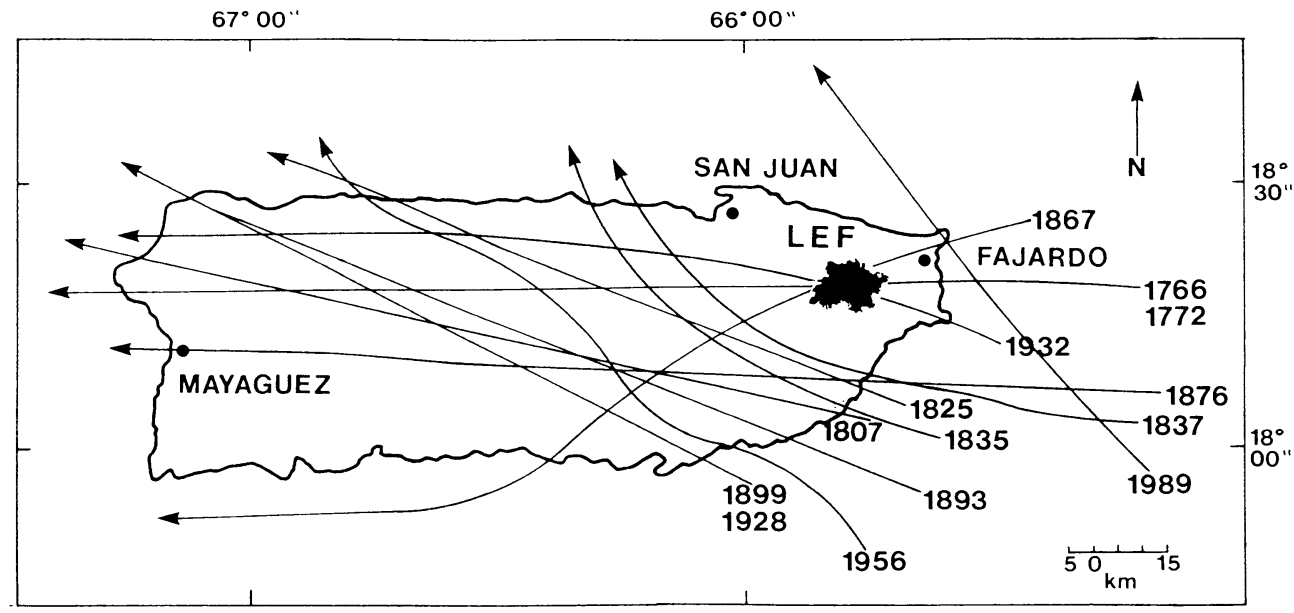

Fig. 1. Puerto Rico. Tracks of severe hurricanes since 1700 (adapted from Salivia 1950, Weaver 1987). LEF $=$ Luquillo Experimental Forest. $1989=$ Hurricane Hugo.

tions to global climate model (GCM) projections of future hurricanes (Emanuel 1987, O'Brien et al. 1992).

In our work we have tried to develop an integrative approach for assessing the ecological characteristics of hurricanes. A simple model (HURRECON) of hurricane surface wind fields, based on meteorological studies and calibrated with meteorological data, provides broad-scale estimates of wind conditions during a storm. A simple topographic exposure model (EXPOS) utilizes wind direction predicted by HURRECON and a digital elevation map to predict site exposure to the strongest winds on a landscape scale. Actual damage to forest stands is assessed through analysis of remotely sensed, historical, and field data.

In the present study we used these techniques to evaluate the characteristics and impacts of two important hurricanes: Hurricane Hugo (1989) in Puerto Rico and the 1938 Hurricane in central New England. Though broadly similar in terms of wind velocity and their catastrophic impact on forest ecosystems, these two storms provide sharp contrasts in their meteorological conditions, and the two regions affected differ greatly in climate, vegetation, physiography, and disturbance regimes. Model predictions were combined with records and maps of forest damage at a regional, landscape, and stand scale to enable a comprehensive assessment of our modeled results and a comparison of the two storms.

\section{Study AREAS \\ Puerto Rico}

Puerto Rico, the easternmost and smallest of the Greater Antilles, is a mountainous island $\approx 55 \times 160$ $\mathrm{km}$ in size. The island is characterized by an east-west mountain ridge terminating in the northeast in the Luquillo Mountains (1075 m above sea level [a.s.l.]). Considerable variation in climate results from the interaction of this topography with the eastern trade winds.
Major life zones include: Subtropical Dry Forest, Subtropical Moist Forest, Subtropical Wet Forest, Subtropical Rain Forest, Lower Montane Wet Forest, and Lower Montane Rain Forest (Holdridge 1946, Ewel and Whitmore 1973). Puerto Rico has experienced $>70$ hurricanes since 1700 (Salivia 1950, Millas 1968, Neumann et al. 1987), including severe storms in 1899 , 1928, 1932, and 1989 (Gifford 1905, Bates 1930, Weaver 1987, Scatena and Larsen 1991). Hurricanes generally approach the island from an easterly direction (Fig. 1). Wind and erosion accompanying hurricanes have repeatedly modified the forests, creating a landscape mosaic of vegetation (Crow and Grigal 1980, Weaver 1986). Hurricanes may play a very important role in maintaining floristic diversity in the tabonuco zone (Doyle 1981, Brown et al. 1983), generating ongoing dynamics of vegetation structure and composition (Wadsworth 1970, Crow 1980, Weaver 1986) and controlling the productivity of the forest ecosystem (Waide and Lugo 1992).

The Luquillo Experimental Forest (LEF) occupies 11230 ha in the Luquillo Mountains of northeastern Puerto Rico and is administered by the USDA Forest Service. In an elevational range from 100 to $1075 \mathrm{~m}$ a.s.l. the LEF encompasses the largest contiguous area of virgin forest in Puerto Rico. Vegetation consisting of tabonuco (100-600 m), colorado (600-800 m), and dwarf forest (ridges $>600 \mathrm{~m}$ ) occupies elevationally defined zones, palm brakes occur on poorly drained soils above $500 \mathrm{~m}$ elevation, and secondary forest occupies lower sites toward the margin of the LEF (Wadsworth 1970, Weaver 1986). The climate is characterized by a mean annual precipitation of $320 \mathrm{~cm}$ and mean temperature of $21^{\circ} \mathrm{C}$ (Briscoe 1966).

\section{Hurricane Hugo}

Hugo was a category 3 hurricane with maximum sustained winds of $57 \mathrm{~m} / \mathrm{s}$ as it passed northwest at 5 
$\mathrm{m} / \mathrm{s}$ over the extreme eastern tip of Puerto Rico on 18 September 1989. Damage to the LEF was severe, particularly at the Bisley study site in the northeastern portion of the LEF, where extensive areas of forest were blown down (Lugo and Scatena 1993). The effects of Hugo are an important focus of research for the Luquillo Long-Term Ecological Research (LTER) program (Waide and Lugo 1992, Lugo and Waide 1993).

\section{New England}

New England comprises a six-state area of $\approx 173000$ $\mathrm{km}^{2}$ in the northeastern United States. Climatic gradients associated with latitude, distance from the coast, and elevation produce considerable regional variation in vegetation. Major forest types include: Central Hardwoods-Hemlock, Transition Hardwoods-White Pine-Hemlock, Northern Hardwoods-Hemlock-White Pine, and Spruce-Fir-Northern Hardwoods (Westveld 1956). New England experiences severe hurricanes on an infrequent basis (Smith 1946). Major historical storms that caused significant forest damage occurred in $1635,1788,1815,1869,1938$, and 1944 (Darling 1842, Perley 1891, Ludlum 1963, Neumann et al. 1987). Hurricanes generally approach New England from the south (Fig. 2).

The 1200-ha Harvard Forest in north-central Massachusetts lies in the Eastern Upland physiographic region with moderate local relief ranging from 220 to $410 \mathrm{~m}$ a.s.l. and vegetation characteristic of the Transition Hardwood-White Pine-Hemlock forest region. The climate is characterized by a mean annual precipitation of $110 \mathrm{~cm}$ and a mean temperature of $7^{\circ} \mathrm{C}(\mathrm{Har}-$ vard Forest Archives [Petersham, Massachusetts, USA], unpublished data).

\section{Hurricane}

The 1938 New England Hurricane was also a category 3 storm as it passed northward over Long Island and across western New England on 21 September. Its rapid forward motion (an extraordinary $25 \mathrm{~m} / \mathrm{s}$ on landfall) and modification by cool temperate air are typical of New England hurricanes (Dunn and Miller 1964). This storm was the most destructive hurricane ever recorded in central New England, where it destroyed much of the standing timber and caused disastrous floods (NETSA 1943). It has had a profound effect on forestry and forest ecology in New England (Stephens 1955, Gould 1960).

\section{Methods}

\section{Meteorological model (HURRECON)}

Modeling hurricane winds. - Meteorological studies of hurricane structure are based on empirical analyses of many individual storms. Such studies indicate that the broad-scale structure of the surface wind field is similar in most hurricanes (Frank 1977, Simpson and Riehl 1981, Anthes 1982). Based on these findings, we

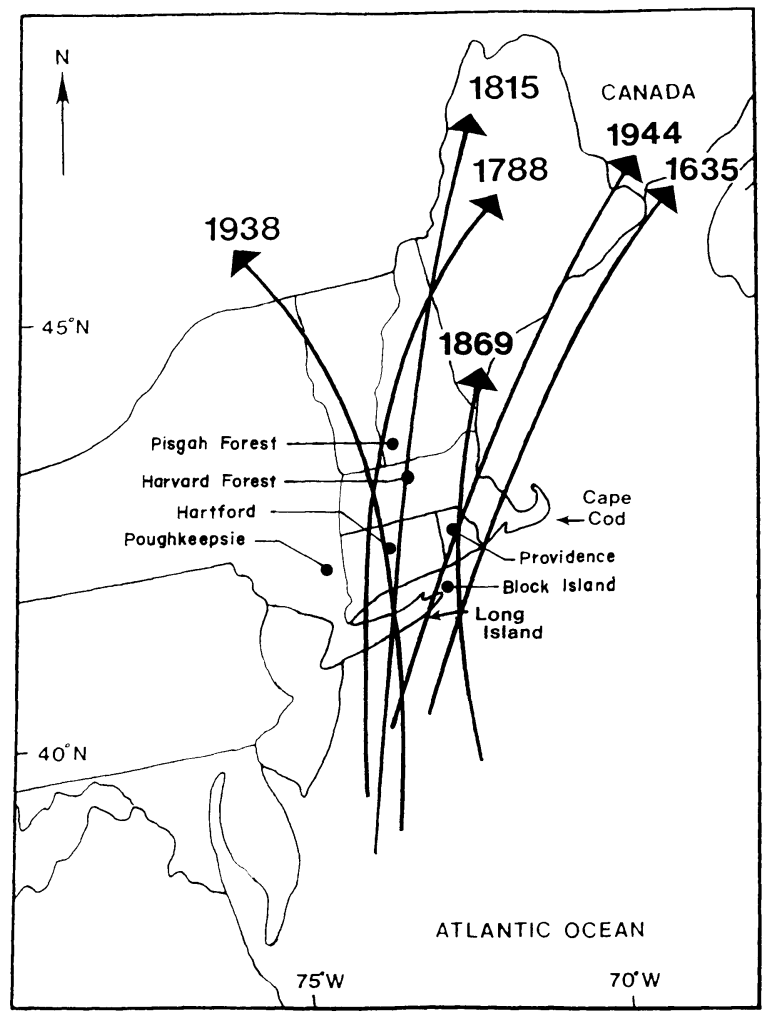

Fig. 2. New England. Tracks of six severe hurricanes that caused significant forest damage (adapted from Smith 1946).

developed a simple model that estimates surface wind conditions (sustained wind speed, peak gust speed, and wind direction) utilizing data on the track, size, and intensity of the hurricane and the surface type (land or water).

Model equations for sustained wind velocity $\left(V_{s}\right)$, peak gust velocity $\left(V_{g}\right)$, sustained wind direction $\left(D_{s}\right)$, and peak gust direction $\left(D_{g}\right)$ at a point $P$ for hurricanes in the northern hemisphere are given below (Fig. 3). Velocity and direction are measured relative to the Earth's surface, and angles are measured in degrees. Parameter values used in this paper are given in parentheses. Note that the highest winds and heaviest precipitation normally occur in the hurricane eyewall surrounding the relatively calm and (frequently) clear central eye.

$$
\begin{aligned}
V_{s}= & F\left[V_{m}-V_{h}(1-\sin A)\right]\left[R / R_{e}\right] \\
& \text { inside the eye } \\
= & F\left[V_{m}-V_{h}(1-\sin A)\right]\left[R_{e} / R\right]^{X} \\
& \text { outside the eye } \\
V_{g}= & G \cdot V_{s} \\
D_{s}= & D_{g}=B-90-I,
\end{aligned}
$$

where $F=$ reduction in sustained wind velocity due to friction (water $=1.0$, land $=0.8), V_{m}=$ maximum 
(a)
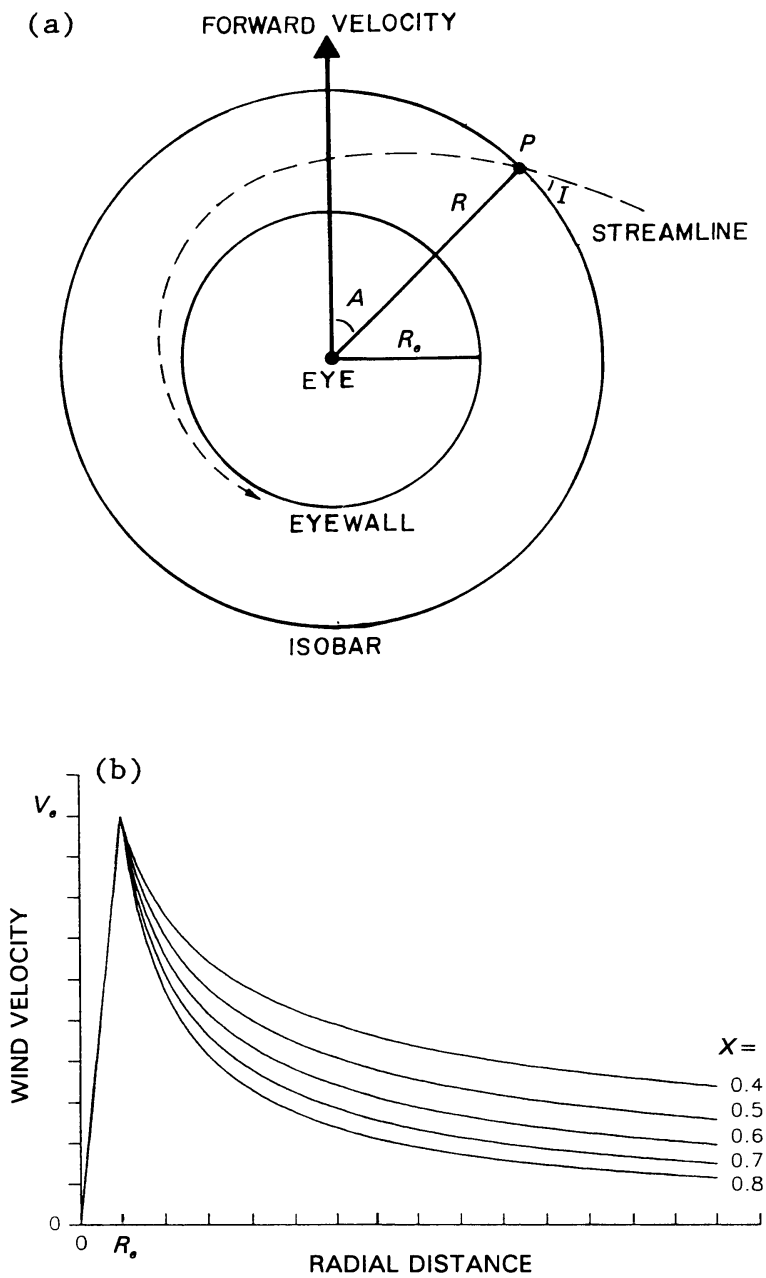

FIG. 3. Meteorological model, HURRECON. (a) At the surface air is drawn into the hurricane along spiral streamlines or trajectories that cross the nearly circular isobars. Model estimates of wind velocity and direction at point $P$ are based in part on $R$ (distance to center of hurricane), $R_{e}$ (radius of hurricane eye), $A$ (angle between forward path of hurricane and radial line to $P$ ), and $I$ (cross-isobar inflow angle). (b) Model estimates of surface wind velocity along a radial line outward from the center of the hurricane, for different values of the wind profile constant $X . R_{e}=$ radius of hurricane eye, $V_{e}=$ wind velocity in eyewall.

sustained wind velocity at any location if the hurricane were entirely over water, $V_{h}=$ forward velocity of hurricane, $A=$ clockwise angle between forward path of hurricane and a radial line from the hurricane center to point $P, R=$ radial distance from hurricane center to point $P, R_{e}=$ radius of eye, $X=$ wind profile constant $(0.4 \leq X \leq 0.8), G=$ gust factor (water $=1.12$, land $=1.4), B=$ compass bearing from point $P$ to hurricane center, $I=$ cross-isobar inflow angle (water $=20^{\circ}$, land $=40^{\circ}$ ). The derivation of these equations and characteristics of the surface wind field are discussed in the Appendix. Note that for a given location the predicted wind speed is a function of storm position, storm speed and direction, eye diameter, current maximum wind speed, wind profile constant, and surface type (land or water), while the predicted wind direction is a function of storm position and surface type. In general the highest wind speeds are predicted to the right of the storm track, where the forward motion of the storm coincides with the rotational motion of the wind around the storm center. Minor adjustments in the model equations are required for hurricanes in the southern hemisphere, where air flow is clockwise around the eye.

The model distinguishes between land and water sites: because of greater surface friction, land sites are normally characterized by lower sustained wind speeds and higher inflow angles (Powell 1982; also see Appendix). In our studies particular sites were characterized as land or water sites depending on the approach path of the highest winds. For regional estimates, maps were digitized on the GIS (Geographical Information System) to indicate the surface type (land or water) of each cell of a regional grid.

The model does not take into account local topography. Surrounding topographic features, particularly in hilly terrain, may modify wind speed and direction at a particular site; large mountains may significantly weaken the storm itself (see Hurricane Hugo, below). The topographic model described below may be used to locate areas on a landscape scale most likely exposed to or protected from the peak winds predicted by the HURRECON model.

The model does not predict convective-scale effects such as spiral rainbands (bands of heavy precipitation that spiral around and into the storm), intense convective cells, or tornadoes; nor the disruptive effects on the storm of large topographic features such as mountains; nor the overall influence on the storm of the surrounding large-scale flow in the atmosphere. The model is less accurate than the sophisticated compositing technique used by meteorologists to study some recent hurricanes (e.g., Powell 1982, 1987); however, the compositing technique requires extensive observational data that are rarely available.

Calibration. - The process of calibrating the model for a particular hurricane has several steps:

1) The model requires fixes of the hurricane center specifying latitude, longitude, and date/time of day in order to compute storm location and the speed and bearing of forward motion.

2) For each fix, the model requires an estimate of the maximum sustained surface wind speed (over water) at any location at that date/time. For recent Atlantic hurricanes (e.g., Hugo) these figures are available from the National Hurricane Center; for older storms (e.g., 1938 Hurricane) they may be estimated from surface wind or pressure measurements.

3) The model requires an estimate of the size of the eye. Where sufficient data are available (normally aerial reconnaissance data; e.g., Hugo), measurements of the eye diameter as a function of date/time may be used. 
For earlier storms (e.g., 1938 Hurricane) a constant diameter may be estimated from available data.

4) The wind profile constant $X$ may be estimated from surface observations if a weather station close to the track survives the storm. The model is used to generate a series of wind speed-vs.-time curves for the station for different values of $X$; these are compared to the observed wind speed curve to determine the best fit (see Meteorological reconstruction sections, below). The value of $X$ could also be calculated from aerial reconnaissance transects, where these have been performed.

If additional meteorological data are available that were not used to calibrate the model, they may be compared to model estimates to test the accuracy of a particular reconstruction.

Wind and forest damage. - The relationship between forest damage and wind speed and duration is complex and not fully understood. Engineering studies to date have focused on the response of human constructions to high winds (e.g., Simpson and Riehl 1981). The response of trees is more complex, especially since the architecture of many trees appears to include features that reduce wind drag as the wind speed increases (e.g., Vogel 1993). It has been hypothesized that much of the damage to forests is caused by wind gusts, especially at higher wind speeds, while lower wind speeds may cause fatigue damage over time (Fujita 1971). In our model we used two measures of wind speed: sustained wind speed $\left(V_{s}\right)$ and peak gust speed $\left(V_{g}\right)$. The first is an estimate of the wind speed averaged over a specified period (U.S. standard $=1 \mathrm{~min}$; international standard $=10 \mathrm{~min}$ ). The second is an estimate of the highest instantaneous gust speed; actual measured values depend on the type and sensitivity of the instruments used. As an indication of the impact on a given site, the model calculates peak gust speed and total energy (the square of the velocity multiplied by time) of sustained winds of gale force $(\geq 17 \mathrm{~m} / \mathrm{s})$ during the storm's passage.

The relationship between treefall orientation and wind direction is also complex. Recent experiments have shown that trees pulled over using a winch and a long cable tend to fall in the direction of the applied force, with some individual variation because of differences in form and rooting conditions (J. Bertram, unpublished data). The direction of hurricane wind gusts tends to be close to the sustained wind direction (see Appendix). Thus if the sustained wind does not change direction and wind gusts are high enough to cause windthrow, we would expect that the average orientation of a large sample of wind-thrown trees should reflect that wind direction.

The direction of the damaging winds normally changes during passage of the hurricane, especially at sites close to the eyewall. In hilly or mountainous areas wind direction may also change as the wind is channelled along alternative paths by the local topography.
Trees that are more susceptible to windthrow may be felled earlier in the storm, at lower wind speeds, than other trees. In areas of steep terrain, the final position of wind-thrown trees may be influenced by the local slope. These factors complicate the interpretation of the treefall data. Their possible influence in both Hurricane Hugo and the 1938 Hurricane is discussed below.

\section{Topographic exposure model (EXPOS)}

Modeling the movement of air around even a simple geometric solid is a difficult problem in fluid dynamics (e.g., Churchill 1988). The problem becomes far more complex if one assumes a complex topographic surface and the meteorological conditions typically found near the center of a hurricane: steep gradients of pressure and velocity, curved wind trajectories, and rainbands and local convective cells. In most cases the storm is moving forward, causing these gradients to change at fixed locations. In addition the storm itself may be intensifying or weakening, further altering the gradients.

Despite these complexities, we found that a very simple topographic exposure model provides useful predictions of areas protected from or exposed to damaging winds. The model works on a landscape scale $(\approx 10 \mathrm{~km})$ and requires an accurate digital elevation map and a specified wind direction. The HURRECON model may be used to provide the peak wind direction or directions for a particular area. The EXPOS model then classifies each point on the elevation map as protected or exposed, depending on whether or not it falls within the wind shadow cast by points upwind. The wind shadow is estimated by assuming that the wind bends downward no more than a fixed inflection angle from the horizontal as it passes over a height of land (Fig. 4).

The modeled inflection of the air stream as it passes over a height of land roughly approximates the wake created in turbulent flow around a stationary object at high Reynolds number (Shapiro 1961, Whitaker 1968, Churchill 1988). The actual path of the air in the vertical plane is more complex than this and depends on factors such as wind speed, air density, surface friction, and the size and shape of the landform. The model does not predict deflection or curvature of the wind in the horizontal plane, and so cannot predict local alterations in wind direction caused by topography.

\section{Hurricane Hugo}

Meteorological reconstruction. - Meteorological data used in the reconstruction of Hurricane Hugo included track and intensity data every $6 \mathrm{~h}$ and at landfalls (Lawrence 1989, NOAA 1989), aerial reconnaissance measurements every 1-7 h (U.S. National Hurricane Center and Hurricane Research Division, unpublished data), and hourly surface observations from San Juan International Airport (U.S. National Climatic Data Center, 


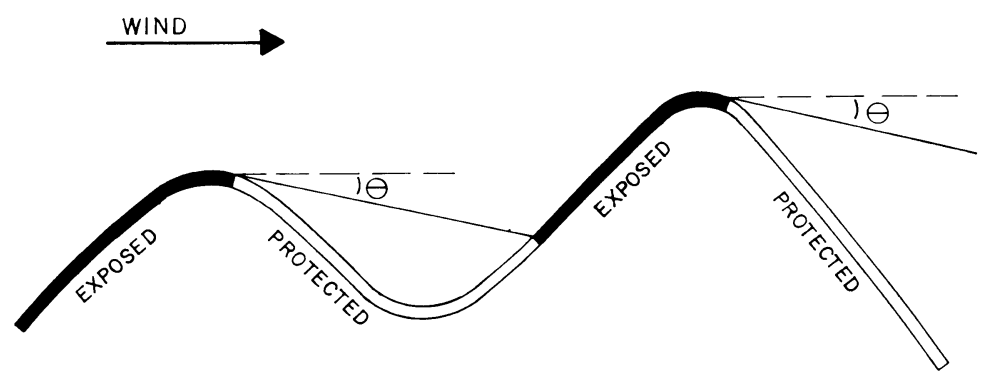

FIG. 4. Topographic exposure model, EXPOS. For a given wind direction, each point in the study area is classified as protected or exposed, depending on whether or not the point falls within the wind shadow cast by points upwind. Wind shadows are estimated by assuming that the wind bends downward no more than a fixed inflection angle $(\theta)$ as it passes over a height of land.

unpublished data). San Juan Airport was the only local station to survive the storm. Wind equipment was lost at two stations closer to the storm track, Roosevelt Roads Naval Base in Ceiba and Alexander Hamilton Airport in Saint Croix (Matos 1989). For modeling purposes San Juan Airport was treated as a water site.
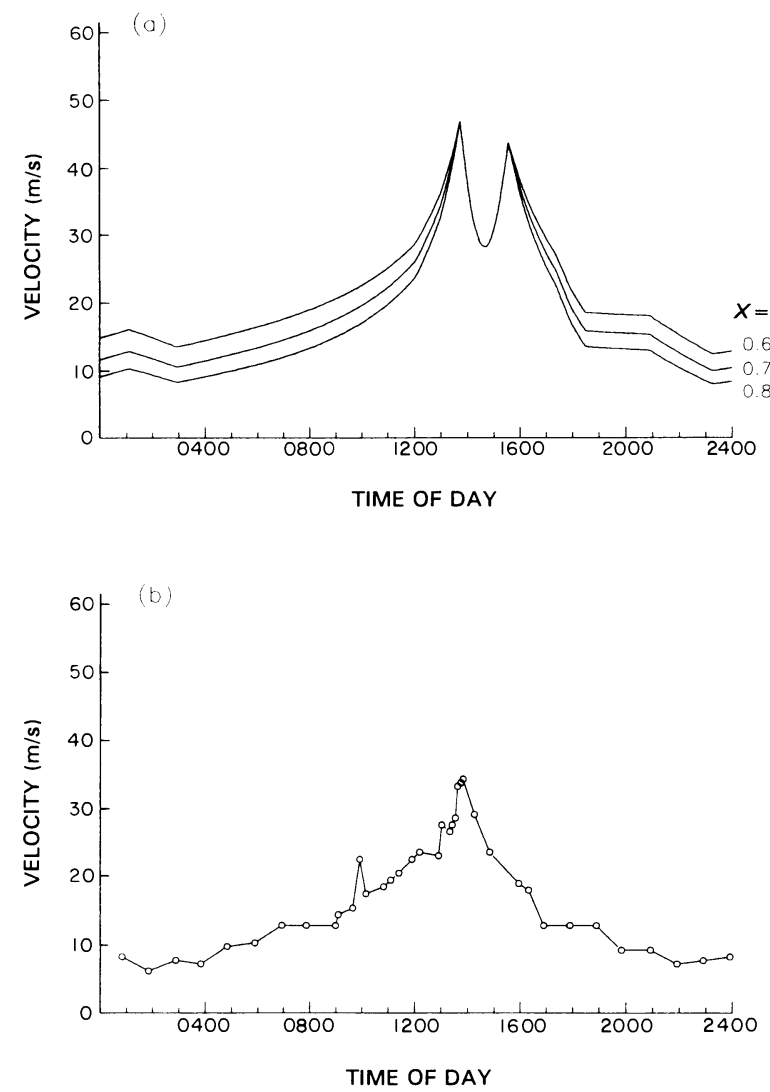

FIG. 5. Calibration of the HURRECON model for Hurricane Hugo using sustained wind velocity data from San Juan Airport on 18 September 1989. (a) Predicted wind velocity for different values of the wind profile constant $X$ and (b) observed wind velocity as a function of time of day (UTC = Coordinated Universal Time, formerly called Greenwich Mean Time).
The HURRECON model was calibrated as follows: 1) The track of the storm was taken directly from the National Hurricane Center report (Lawrence 1989).

2) Maximum 1-min sustained wind speeds were taken directly from the National Hurricane Center report (Lawrence 1989), with modifications for the period 1200 on 18 September 1989 through 0600 on 19 September 1989 UTC (Coordinated Universal Time, $\equiv$ Greenwich Mean Time) as described below (in item 5).

3) Eye diameters as a function of date/time of day were taken directly from the Reconnaissance Fix Log at the National Hurricane Center. Where the eye was recorded as elliptical, the diameter was calculated as the average of the major and minor axes of the ellipse.

4) The wind profile constant $X$ was estimated by comparing observed 1-min sustained wind speeds at San Juan Airport with model estimates for different values of $X$ (Fig. 5). A value of $X=0.8$ was found to provide a good fit for the period 0000 through 1200 on 18 September as the storm approached Puerto Rico over water, before it was weakened by landfall (see below). Actual inflow angles at the Airport during the height of the storm were calculated from the track data, assuming circular isobars.

5) The track and eye data from the National Hurricane Center indicated that the western edge of the eye passed to the west of San Juan. When the model was calibrated with these data, it predicted the arrival at the Airport of the leading eyewall to within $5 \mathrm{~min}$ of the observed peak wind. If the eyewall had passed to the east of San Juan as first reported (Matos 1989), then the peak wind would have occurred at the point of closest approach, $\approx 1 \mathrm{~h}$ later. Meteorologists at the Hurricane Research Division believe that upon landfall Hugo actually jogged slightly to the west of the National Hurricane Center track ( $\mathrm{H}$. Willoughby, personal communication). However, the observed wind speed at the Airport showed a lower peak value than predicted, and little evidence of the passage of the trailing eyewall (Fig. 5), suggesting that the storm was significantly weakened as it passed over the Luquillo Mountains (1075 m above sea level [a.s.l.]). Aerial re- 
TABLE 1. Maximum sustained wind speed estimates for Hurricane Hugo from the National Hurricane Center (NHC) and modified values used in the model to simulate weakening of the storm after landfall in September 1989.

\begin{tabular}{cccc}
\hline \hline $\begin{array}{c}\text { Date/time* } \\
\text { (UTC) }\end{array}$ & $\begin{array}{c}\text { NHC } \\
\text { values } \\
(\mathrm{m} / \mathrm{s})\end{array}$ & $\begin{array}{c}\text { Model } \\
\text { values } \\
(\mathrm{m} / \mathrm{s})\end{array}$ & Notes \\
\hline $18 / 1200$ & 57 & 57 & Landfall at Vieques \\
$18 / 1300$ & 57 & 50 & Landfall at Fajardo \\
$18 / 1400$ & & 43 & \\
$18 / 1500$ & & 33 & \\
$18 / 1800$ & 54 & 33 & \\
$19 / 0000$ & 51 & 46 & \\
$19 / 0600$ & 46 & 46 & \\
\hline
\end{tabular}

* Time of day. UTC $=$ Coordinated Universal Time (formerly called Greenwich Mean Time).

connaissance data confirmed this hypothesis: average peak wind speeds at an altitude of $4 \mathrm{~km} \mathrm{6-8} \mathrm{h}$ after landfall were roughly two-thirds of what they were 13$19 \mathrm{~h}$ before landfall (Hurricane Research Division, unpublished data). Even greater weakening may have occurred at surface levels, since the hurricane boundary layer responds to landfall more quickly than upper levels (Powell 1987; H. Willoughby, personal communication). This weakening was simulated in the model by modifying the maximum sustained wind speed estimates from the National Hurricane Center (Table 1) so that the predicted sustained wind speed at the Airport closely matched the observed values (see Results: Hurricane Hugo, below). The introduced values simulated a steady reduction of sustained wind energy (square of the velocity) over a 3 -h period and $3 \mathrm{~h}$ as a minimal hurricane $(33 \mathrm{~m} / \mathrm{s})$ before the storm reintensified.

Once calibrated, the model was used to generate regional estimates of wind conditions over a $180 \times 180$ $\mathrm{km}$ grid (cell size $=1 \times 1 \mathrm{~km}$ ) centered on eastern Puerto Rico. A GIS overlay of land and water areas was used by the model to identify the surface type of each cell. Wind conditions were also calculated at four points along an east-to-west transect at latitude $18^{\circ} 19^{\prime}$ $\mathrm{N}$ in the Northern Luquillo Experimental Forest (LEF) study area (Fig. 6): the Bisley $\left(65^{\circ} 45^{\prime} \mathrm{W}\right.$ ) and El Verde $\left(65^{\circ} 49^{\prime} \mathrm{W}\right)$ field sites, and points at the east $\left(65^{\circ} 44^{\prime} \mathrm{W}\right)$ and west $\left(65^{\circ} 50^{\prime} \mathrm{W}\right)$ edges of the study area. For modeling purposes these points were treated as land sites. Output for all four sites was used to estimate the range in peak wind speed and direction across the Northern LEF study area and to obtain average values for use with the topographic exposure model. Predictions for Bisley and El Verde were compared to treefall data from the Eastern LEF study area and El Verde, respectively (Fig. 6).

Topographic exposure. - An elevation map of the LEF at 30-m resolution (digitized from 1:24000 USDA Forest Service map) was used to predict protected and exposed areas in the Northern LEF study area using the peak $340^{\circ}(\mathrm{NNW})$ wind predicted by the meteo- rological model and inflection angles from $2^{\circ}$ to $12^{\circ}$. Exposure was also estimated for an inflection angle of $6^{\circ}$ and wind directions from $270^{\circ}$ clockwise to $90^{\circ}$, in $10^{\circ}$ increments. The vegetation damage map for this study area (see below) was recoded to reflect average percentage damage for each class: class $1=0 \%$ average windthrow, class $2=5 \%$, class $3=25 \%$, class $4=58 \%$, class $5=88 \%$. This map was used to calculate average damage in protected and exposed areas for different sections of the study area and different inflection angles. A simplified damage map was derived in two classes: low damage $=$ class $1-2(<10 \%$ windthrow $)$ and high damage $=$ classes $3-5(\geq 10 \%)$. This map was used to calculate the association (using Cole's coefficient; see below) between protected areas and low damage in different sections of the study area for an inflection angle of $6^{\circ}$ and a range of wind directions. Finally, the elevation map for the entire LEF was used to study protected and exposed areas across the LEF for the predicted peak wind direction $\left(340^{\circ}\right)$ and an inflection angle of $6^{\circ}$.

Broad-scale damage patterns. - Forest damage was mapped across the Northern LEF study area from aerial photographs (color infrared; 1:24 000; August 1990) with a lens stereoscope $(4 \times$ magnification). Damage was assessed in five severity classes, corresponding to the following percentage of wind-thrown trees: class 1 $=0 \%$ windthrow, class $2=1-9 \%$, class $3=10-39 \%$, class $4=40-74 \%$, class $5=75-100 \%$. The smallest damage patch recognized was 1.3 ha. The aerial interpretations were transferred to a base map (1:24000, USDA Forest Service) and then digitized onto the GIS. Other digitized information included elevation (see Topographic exposure, above) and forest vegetation (USDA Forest Service, unpublished data).

Analysis of the spatial pattern of damage and its

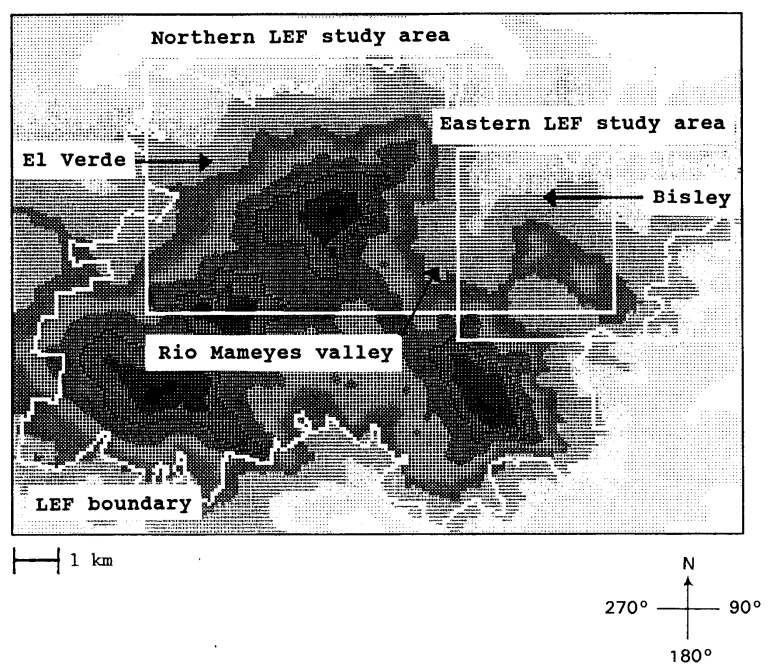

FIG. 6. Study areas in the Luquillo Experimental Forest (LEF; Puerto Rico). Elevation shown in 100-m contours ranges from 50 to $1075 \mathrm{~m}$ above sea level (a.s.1.). 

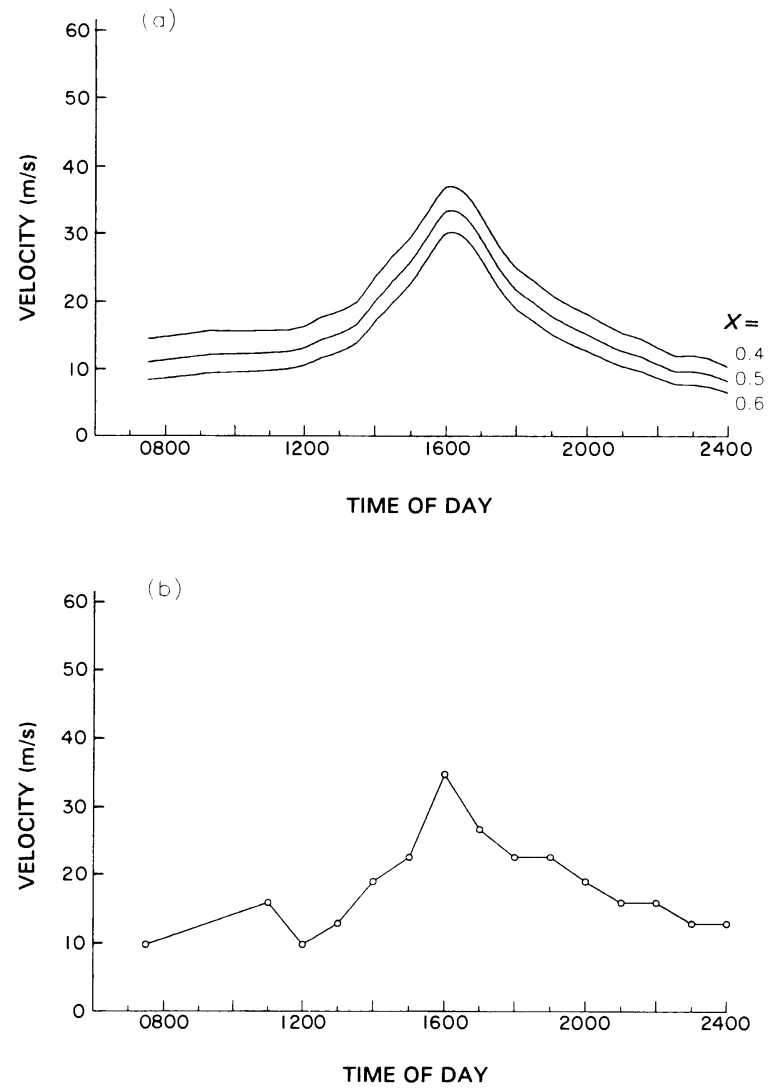

FIG. 7. Calibration of the HURRECON model for the 1938 New England Hurricane using sustained wind velocity data from Providence (Rhode Island, USA) on 21 September 1938. (a) Predicted wind velocity for different values of the wind profile constant $X$ and (b) observed wind velocity as a function of time of day (EST = Eastern Standard Time).

association with landscape characteristics was undertaken on the GIS. Summary statistics and an index of the strength of association between damage classes and site characteristics were calculated from GIS overlays. The index of association utilized was Cole's coefficient (Cole 1949, Foster and Boose 1992). Coefficient values range from -1 (maximum disassociation) to 0 (no association) to 1 (maximum association).

Treefall orientation. - Treefall orientation was assessed across the Eastern LEF study area (Fig. 6), a $17-\mathrm{km}^{2}$ area for which damage intensity was high and cloud-free aerial photography available (true color; 1:18 000; February 1990). This study region ranges from 100 to $660 \mathrm{~m}$ a.s.l., includes the headwaters of the Sabana and Mameyes Rivers, and is approximately bisected by the Rio del Cristal. A total of 2598 windthrown trees were mapped from the aerial photographs using a lens stereoscope. The orientation of each mapped stem was measured to the nearest degree and subsequently grouped into categories of $10^{\circ}$. Within the study region 108 areas containing treefalls and ranging in size from 0.5 to 29 ha were delineated and categorized according to physiography.
Treefall orientation at El Verde (Fig. 6) was assessed using data collected by the Luquillo LTER Program. The orientations of 1712 severely damaged trunks in a 16 -ha plot $(320 \times 500 \mathrm{~m})$ were measured in the field to the nearest degree (J. Zimmermann, personal communication). The data were then grouped into categories of $10^{\circ}$.

\section{Hurricane}

Meteorological reconstruction. - Our primary source of meteorological data for the 1938 Hurricane was the surface weather charts compiled by C. Pierce (1939). Charts used to calibrate the model were for 0730 on 21 September and hourly from 1100 on 21 September through 0000 on 22 September EST (Eastern Standard Time). Pierce's wind speeds were 5-min averages in the Beaufort scale.

The HURRECON model was calibrated as follows:

1) The track of the storm was measured directly from Pierce's charts.

2) Maximum sustained wind speeds were calculated from Pierce's estimates of central pressure as follows:

$$
V_{m}=22.8 \cdot\left(101.3-P_{c}\right)^{1 / 2}
$$

where $V_{m}=$ maximum 1 -min sustained surface wind speed (over water) in metres per second and $P_{c}=$ central pressure in kilopascals. This equation was adapted from published equations (e.g., Fletcher 1955, Dunn and Miller 1964, Atkinson and Holliday 1977, Simpson and Riehl 1981) to provide a good fit between the proposed values for maximum 1-min sustained wind speed and central pressure in the Saffir/Simpson damage scale (Simpson and Riehl 1981). Model predictions based on these calculated values for $V_{m}$ were found to agree well with the 5 -min observed values reported by Pierce.

3) In the absence of aerial reconnaissance measurements of the hurricane's eye, the eye diameter was set to a constant value of 50 nautical miles $(92.7 \mathrm{~km})$, in accordance with the estimate of the ring of maximum winds at $93 \mathrm{~km}$ (Simpson and Riehl 1981) and with surface reports from Long Island, New York, indicating that the calm portion of the eye was $\approx 80 \mathrm{~km}$ in diameter (Tannehill 1938, Pierce 1939, Brooks 1940).

4) The wind profile constant $X$ was set at a value of 0.4 by comparing observed wind speeds at Providence, Rhode Island (Pierce 1939), with model estimates for different values of $X$ (Fig. 7). Providence was treated as a water site.

Once calibrated, the model was used to estimate wind conditions at three sites from east to west across the storm track (Fig. 2). Of these, Block Island, Rhode Island, was treated as a water site and Hartford, Connecticut, and Poughkeepsie, New York, were treated as land sites. Model predictions were compared to observed values, and actual inflow angles during the height of the storm were calculated from the track data (as- 
suming circular isobars) for all three sites and for Providence. Regional estimates were generated for wind conditions over a $480 \times 720 \mathrm{~km}$ grid (cell size $=4 \times$ $4 \mathrm{~km}$ ) centered on Massachusetts, and a GIS overlay of land and water areas was used by the model to identify the surface type of each cell. The range in predicted peak wind speed and direction from east to west across the town of Petersham, Massachusetts, was calculated. Finally, wind conditions were estimated for two study sites in central New England: the Harvard Forest in Petersham $\left(42^{\circ} 32^{\prime} \mathrm{N}, 72^{\circ} 11^{\prime} \mathrm{W}\right)$ and the Pisgah Forest in Winchester, New Hampshire $\left(42^{\circ} 49^{\prime} \mathrm{N}\right.$, $72^{\circ} 27^{\prime} \mathrm{W}$ ). Output for Harvard Forest was used as input to the exposure model for the town of Petersham, and output for both sites was compared to treefall data.

Topographic exposure. - An elevation map of Petersham at 60-m resolution (digitized from 1:24000 USGS topographic map) was used to predict protected and exposed areas using the peak $135^{\circ}$ (southeast) wind predicted by the HURRECON model and inflection angles from $2^{\circ}$ to $12^{\circ}$. The locations of undamaged and destroyed mature Pinus strobus (white pine) stands were compared to protected and exposed areas for different inflection angles (see next section).

Broad-scale damage patterns. - Information concerning forest damage across New England from the 1938 Hurricane was derived from maps compiled by the Northeastern Timber Salvage Administration, a United States government agency responsible for organizing the salvage and sale of forest products (NETSA 1943). The maps depict by township throughout New England the volume of marketable timber in four classes, interpreted as representing levels of damage intensity: no damage, light damage $\left(<2400 \mathrm{~m}^{3}\left[10^{6}\right.\right.$ board feet]), moderate damage (2400-24000 $\left.\mathrm{m}^{3}\right)$, and severe damage $\left(>24000 \mathrm{~m}^{3}\right)$.

For evaluation of EXPOS and assessment of the landscape pattern of damage, maps of forest vegetation and damage for the town of Petersham were utilized (Harvard Forest Archives, unpublished data). The location and extent of the vegetation most susceptible to damage (white pine stands $>30$ yr old; Foster 1988a) were digitized on the GIS and then compared to the distribution of exposed and protected areas predicted by the EXPOS model.

Treefall orientation. - The orientation of windthrown trees was assessed for the Harvard Forest and the Pisgah Forest, a virgin forest tract owned by Harvard University in Winchester, New Hampshire, 37 $\mathrm{km}$ to the northwest of Harvard Forest. The Harvard Forest data were collected by W. Rowlands (1941; Foster $1988 a$ ) from $>100$ stands that were fully exposed to the wind and completely damaged. The Pisgah Forest data were collected from plots distributed throughout the forest area, which was entirely wind-thrown (Foster 1988b). In both locations tree species and diameters were recorded. At Harvard Forest tree orientations were measured to the nearest degree and later grouped into categories of $5^{\circ}$. At Pisgah Forest tree orientations were measured to the nearest $30^{\circ}$.

\section{RESULTS}

\section{Hurricane Hugo}

Meteorological reconstruction. - The San Juan Airport sustained wind velocity data were used to set the value of the wind profile constant $X$ and to estimate maximum wind speed values as Hugo weakened over land. Thus they could not provide an independent check of the reconstruction. However, after calibration, predicted sustained wind speeds at the Airport did match actual sustained wind speeds generally to within $<5$ $\mathrm{m} / \mathrm{s}$ (Fig. 8). Observed peak gust speeds averaged 5-8 $\mathrm{m} / \mathrm{s}$ higher than predicted, suggesting that the gust factor at the Airport was closer to 1.2 than 1.12, the value used in the model for water sites.

Wind direction data from the Airport were not used to calibrate the model. As the storm first approached (while wind speeds were still low) the observed winds reflected the normal trade wind direction and did not yet converge toward the hurricane. During and after the height of the storm, observed and predicted direction values for both sustained winds and peak gusts agreed generally to within $20^{\circ}$ (Fig. 8). The actual inflow angle of sustained winds at the Airport during the height of the storm averaged $19^{\circ}$ (Table 2 ).

The model predicted that the northeastern eyewall (see Methods: Meteorological model (HURRECON): Modeling hurricane winds, above) contained the highest winds (predicted gusts of $62 \mathrm{~m} / \mathrm{s}$ ) and passed over the island of Culebra (Fig. 9); the highest actual wind gust recorded during Hugo's history $(76 \mathrm{~m} / \mathrm{s})$ was measured in Culebra harbor (Lawrence 1989). Regional reconstructions of wind conditions showed an east-towest gradient of maximum wind speed across eastern Puerto Rico caused by the storm track and the simulated weakening of the storm after landfall (Fig. 9). This gradient agreed with general reports of property damage across the region; e.g., the hardest hit communities, notably Naguabo, Ceiba, Fajardo, and Luquillo, were located on the eastern tip of the island (Matos 1989, Scatena and Larsen 1991).

In the Luquillo Experimental Forest (LEF) the model predicted that peak winds were associated with the leading eyewall. From east to west across the Northern LEF study area, moving away from the storm track, the model predicted a westward shift of $17^{\circ}$ in the peak NNW wind (Table 3). A decrease in peak gust speed of $7 \mathrm{~m} / \mathrm{s}$ from east to west was predicted, corresponding to a $25 \%$ reduction in wind energy (velocity squared), over a period of $34 \mathrm{~min}$. The model predicted that the trailing eyewall passed over the same region $\approx 2 \mathrm{~h}$ later, attended by much lower winds from the southwest or SSW.

Actual damage patterns across the LEF agreed with the model estimates: most of the damage was concen- 

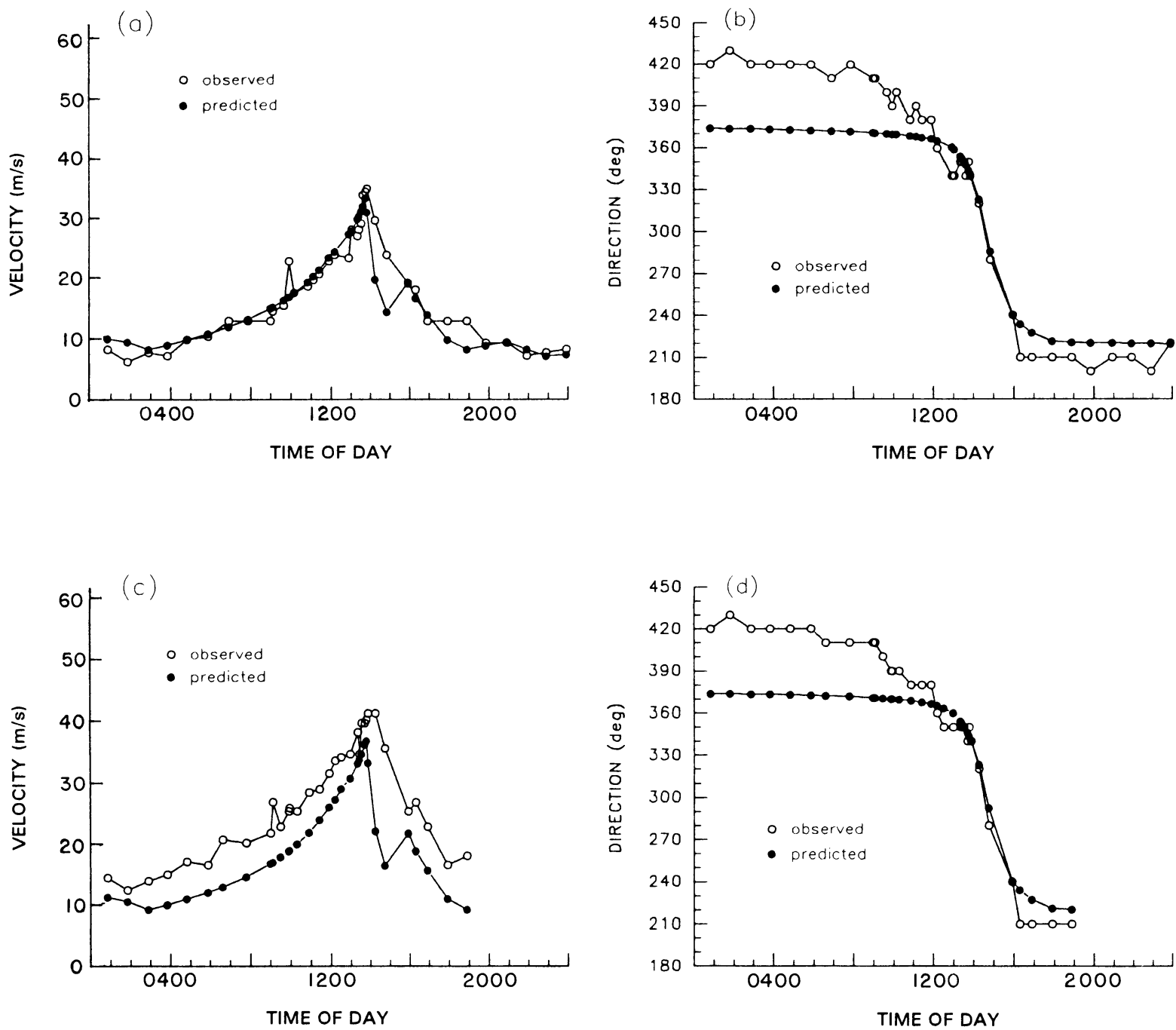

Fig. 8. Observed and predicted wind at San Juan Airport on 18 September 1989 during Hurricane Hugo. (a) Sustained wind velocity, (b) sustained wind direction, (c) peak gust velocity, and (d) peak gust direction as a function of time of day (UTC; for definition see Table 3).

trated on north-facing slopes, while south-facing slopes, exposed to the southwest or SSW winds of the trailing eyewall, showed little damage (Scatena and Larsen 1991). In the Eastern LEF study area, only $9 \%$ of the

TABLE 2. Inflow angles (relative to circular isobars) at selected sites during the height of the hurricane.

\begin{tabular}{|c|c|c|c|c|}
\hline \multirow[b]{2}{*}{ Site } & \multicolumn{2}{|c|}{$\begin{array}{l}\text { Observed inflow } \\
\text { angle }\left({ }^{\circ}\right)\end{array}$} & \multirow{2}{*}{$\begin{array}{l}\text { Mini- } \\
\text { mum } \\
\text { velocity } \\
(\mathrm{m} / \mathrm{s})\end{array}$} & \multirow{2}{*}{$\begin{array}{c}\text { Inflow angle } \\
\text { used in } \\
\text { model } \\
\left({ }^{\circ}\right)\end{array}$} \\
\hline & Mean & SD & & \\
\hline \multicolumn{5}{|c|}{ Hurricane Hugo } \\
\hline San Juan & $19^{\circ}$ & $14^{\circ}$ & 17 & $20^{\circ}$ (water) \\
\hline \multicolumn{5}{|c|}{1938 Hurricane } \\
\hline Providence & $25^{\circ}$ & $18^{\circ}$ & 17 & $20^{\circ}$ (water) \\
\hline Block Island & $27^{\circ}$ & $15^{\circ}$ & 17 & $20^{\circ}$ (water) \\
\hline Hartford & $25^{\circ}$ & $5^{\circ}$ & 11 & $40^{\circ}$ (land) \\
\hline Poughkeepsie & $43^{\circ}$ & $21^{\circ}$ & 11 & $40^{\circ}$ (land) \\
\hline
\end{tabular}

treefall orientations indicated winds from the southwest quadrant $\left(180^{\circ}-270^{\circ}\right)$. The actual east-to-west damage gradient across the Northern LEF study area was even stronger than the model predictions suggested; e.g., while damage at El Verde was scattered and largely confined to defoliation and branch break, much of the Bisley area sustained catastrophic damage, including massive uprooting or breakage of the majority of stems. Both the damage gradient and the model reconstruction suggested that Hugo's eyewall struck the eastern edge of the LEF with full force, but weakened dramatically as it swept westward across the LEF and over the larger mountains.

Model estimates for Bisley predicted that the highest winds did not vary much in direction from the predicted peak at $342^{\circ}$ (Fig. 10). Analysis of treefall data for the Eastern LEF study area showed a major peak from the northwest $\left(\approx 315^{\circ}\right)$ and a minor peak from 
(a)

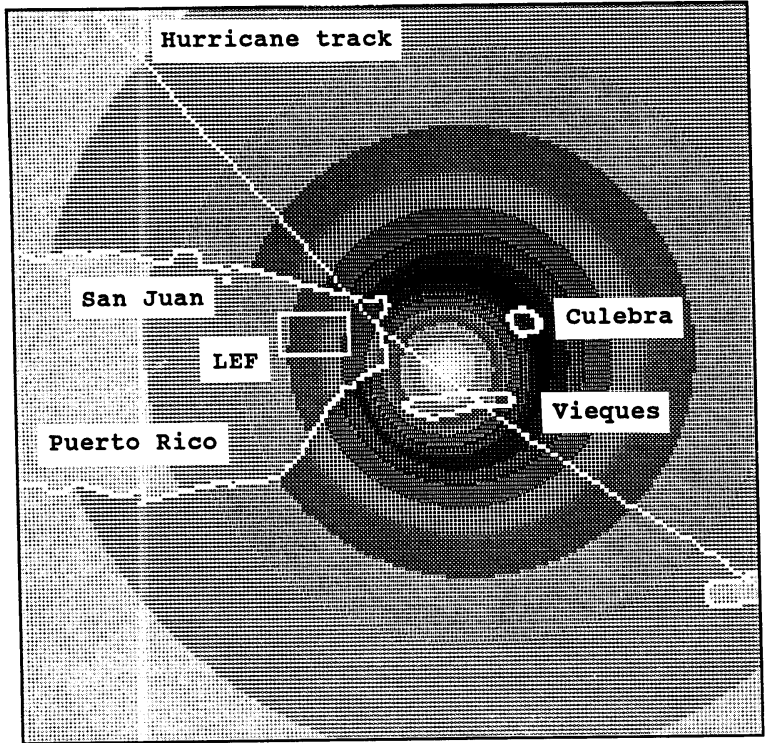

(c)

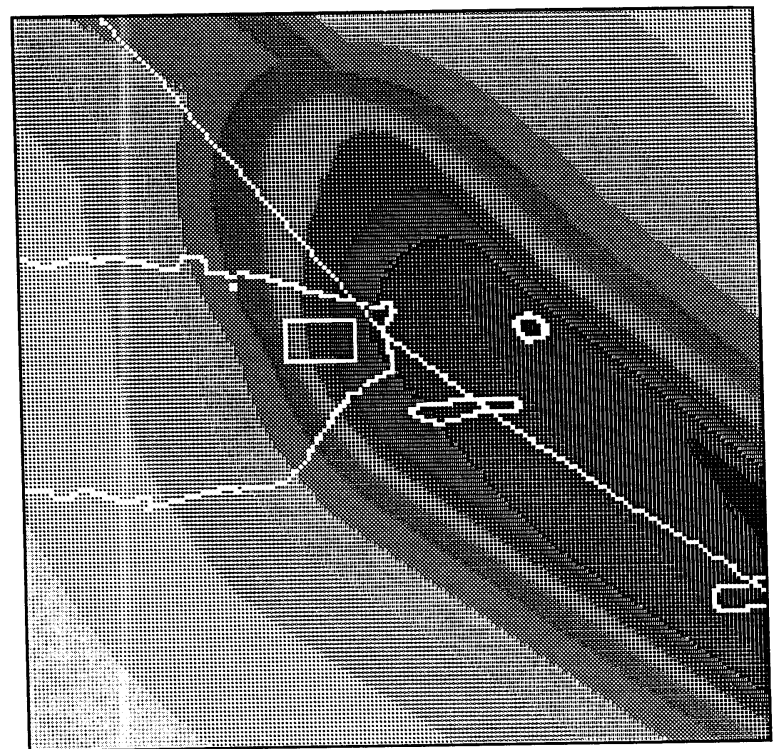

(b)
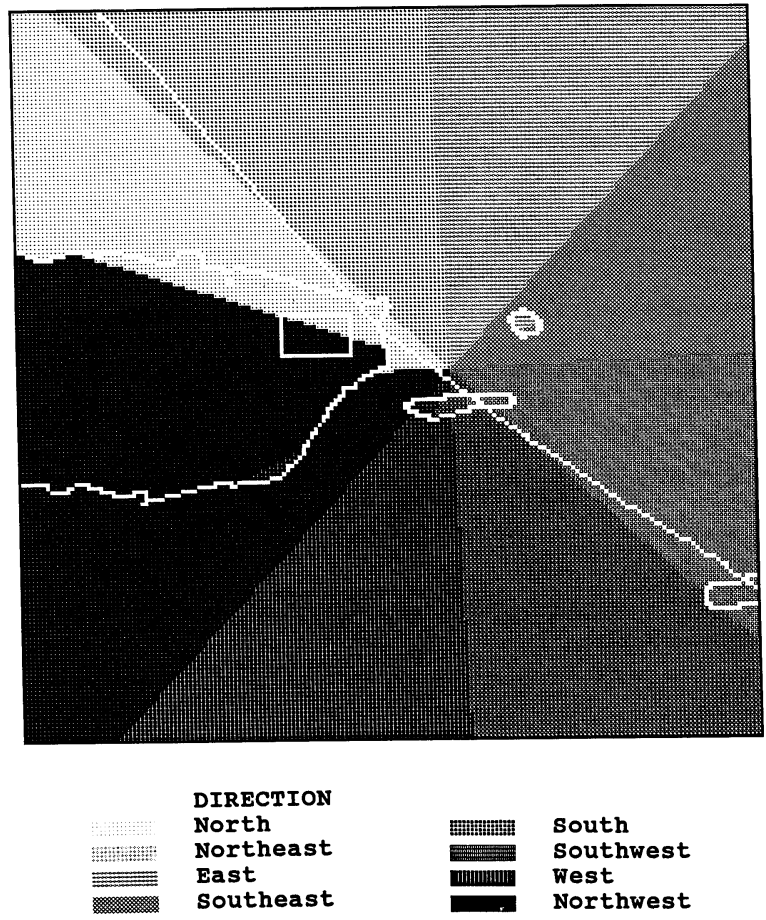

(d)

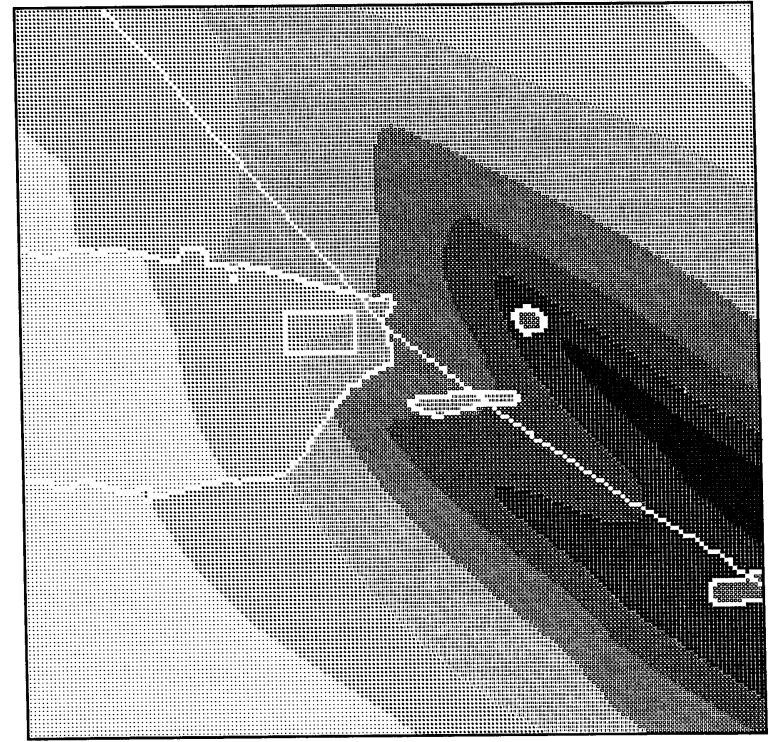

Fig. 9. Predicted wind over a $180 \times 180 \mathrm{~km}$ grid on 18 September 1989 during Hurricane Hugo. Cell size $=1 \times 1 \mathrm{~km}$. (a) Predicted sustained wind velocity and (b) predicted sustained wind direction at 1200 UTC (for "UTC" see Table 3). (c) Predicted maximum wind gust velocity and (d) predicted total energy of sustained winds of gale strength (17 m/s) or greater over a $24-\mathrm{h}$ period (time step $=2 \mathrm{~min}$ ). 
TABLE 3. Predicted peak winds in Hurricane Hugo with the leading and trailing walls of the hurricane eye (the eyewall). Sites are located from east to west across the Northern Luquillo Experimental Forest (LEF) study area at latitude $18^{\circ} 19^{\prime} \mathrm{N}$.

\begin{tabular}{lcccc}
\hline \hline \multicolumn{1}{c}{ Site } & $\begin{array}{c}\text { Time of } \\
\text { day } \\
(\mathrm{UTC}) *\end{array}$ & $\begin{array}{c}\text { Wind } \\
\text { direction } \\
\left({ }^{\circ}\right)\end{array}$ & $\begin{array}{c}\text { Sustained } \\
\text { velocity } \\
(\mathrm{m} / \mathrm{s})\end{array}$ & $\begin{array}{c}\text { Gust } \\
\text { velocity } \\
(\mathrm{m} / \mathrm{s})\end{array}$ \\
\hline \multicolumn{5}{c}{ Leading edge of eyewall } \\
East edge & 1216 & 346 & 39 & 55 \\
Bisley & 1222 & 342 & 39 & 54 \\
El Verde & 1246 & 331 & 35 & 49 \\
West edge & 1250 & 329 & 34 & 48 \\
\multicolumn{5}{c}{} \\
East edge & 1442 & 202 & 22 & 31 \\
Bisley & 1444 & 205 & 22 & 30 \\
El Verde & 1450 & 216 & 20 & 28 \\
West edge & 1451 & 217 & 20 & 27 \\
\hline
\end{tabular}

* UTC $=$ Coordinated Universal Time (formerly called Greenwich Mean Time).

the northeast $\left(\approx 45^{\circ}\right.$; see Treefall orientation, below). The major peak was thus $\approx 27^{\circ}$ to the west of the predicted peak wind direction. The difference may have resulted, at least in part, from westward deflection of the wind along the northeast-facing slopes of the central mountain ridge in the study area, while the minor peak may have been the result of wind channelling up the prominent Rio Mameyes valley, which rises toward the southwest and bisects the northern slopes of the Luquillo range (Fig. 6). Evidence for this lies in the fact that the western edge of the Eastern LEF study area (near the Rio Mameyes) showed a greater percentage of treefall from the northeast (see Treefall orientation, below), while the model (ignoring local topography) predicted that the peak winds should be more nearly westerly as one moved westward away from the storm track. Further evidence was found in the analysis of topographic exposure discussed in the next section.

At El Verde, the average orientation of severely damaged trunks was $340^{\circ}$ (wind direction), $9^{\circ}$ to the east of the predicted peak wind direction and within the likely accuracy of the model.

Topographic exposure. - Protected areas in the Northern LEF study area, predicted by the topographic exposure model (EXPOS) using the peak wind direction $\left(340^{\circ}\right)$ from the meteorological model (HURRE$\mathrm{CON}$ ) and an inflection angle of $6^{\circ}$, matched fairly closely the areas of low damage (Fig. 11). The match was poorest along the western edge of the study area where little damage occurred even on exposed sites, paralleling the east-to-west gradient in wind speed predicted by HURRECON. Patterns of protected and exposed areas in this mountainous terrain were quite sensitive to changes in the inflection angle and changed abruptly with relatively small changes in wind direction (Fig. 11).

Analysis of exposure in the west, central, and east sections of the study area showed that the percentage
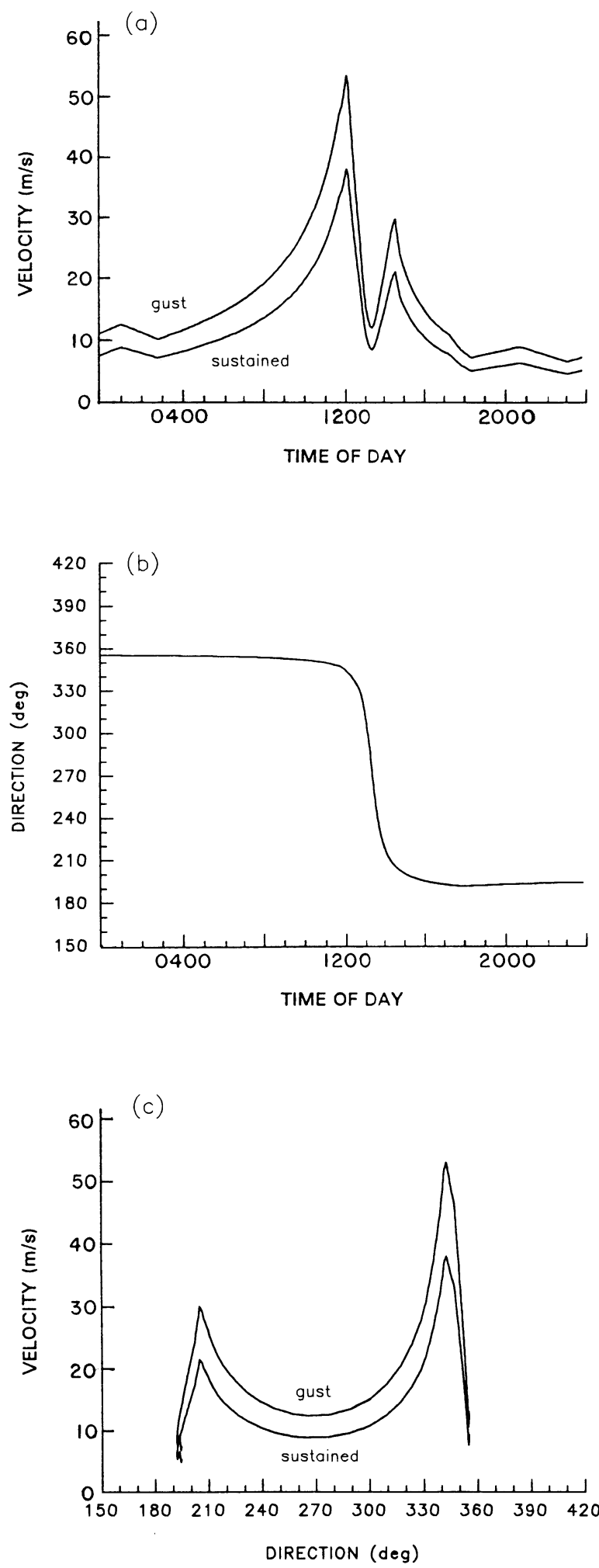

Fig. 10. Predicted wind at the Bisley study site on 18 September 1989 during Hurricane Hugo. (a) Predicted wind velocity and (b) predicted wind direction as a function of time of day (UTC; for definition see Table 3). (c) Predicted wind velocity as a function of wind direction. 
(a)

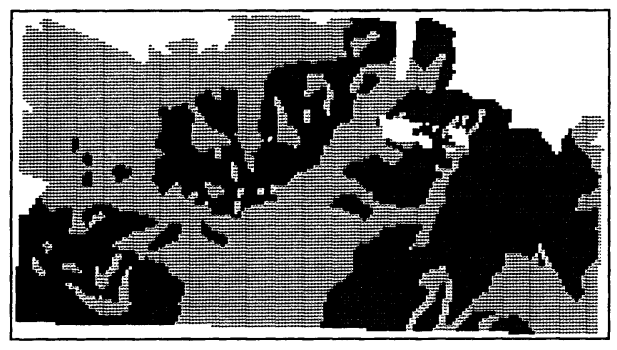

(c)

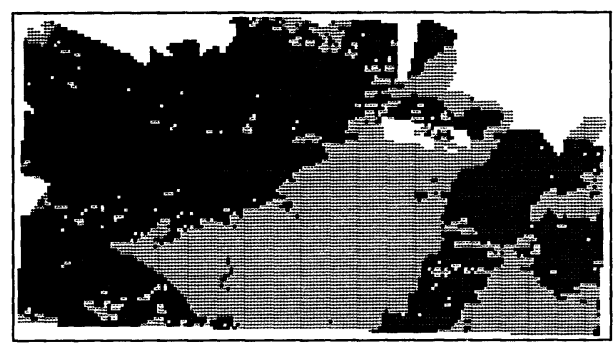

(e)

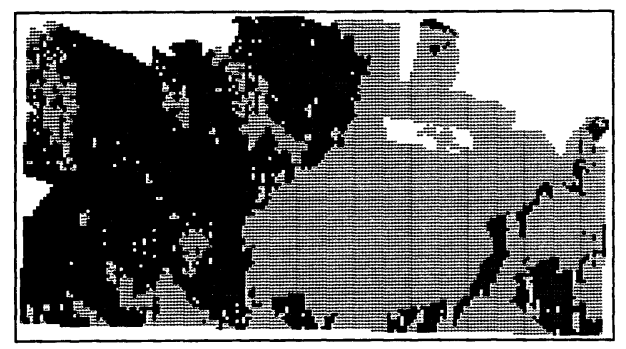

(b)

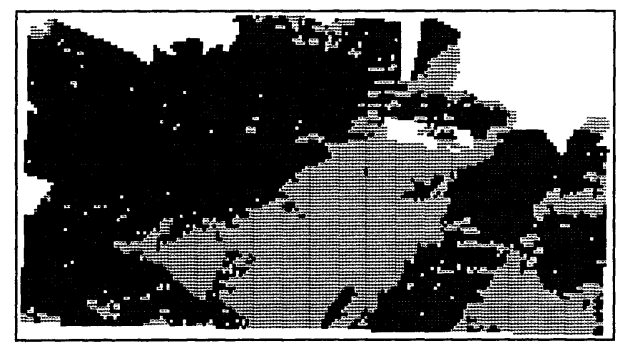

(d)

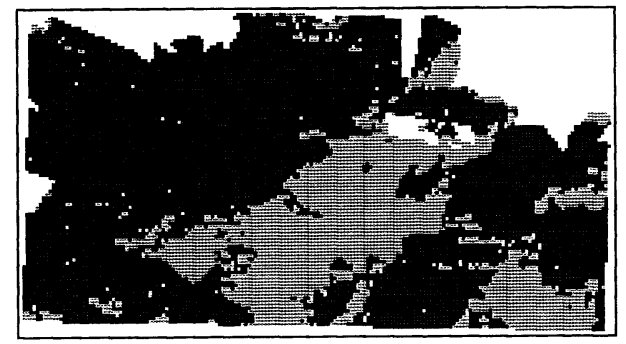

(f)

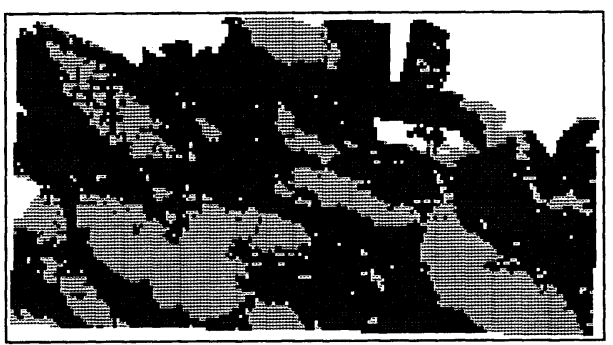

Fig. 11. Forest damage from Hurricane Hugo and predicted exposure in the Northern Luquillo Experimental Forest (LEF) study area. White $=$ outside study area. (a) Forest damage: light grey $=<10 \%$ windthrow; dark grey $=\geq 10 \%$ windthrow. (b) Predicted exposure: wind direction $=340^{\circ}$; inflection angle (downward curvature of airflow path) $=6^{\circ}$; light grey: protected; dark grey: exposed. (c) Predicted exposure: wind direction $=340^{\circ}$; inflection $=4^{\circ}$. (d) Predicted exposure: wind direction $=$ $340^{\circ}$; inflection $=8^{\circ}$. (e) Predicted exposure: wind direction $=280^{\circ}$; inflection $=6^{\circ}$. (f) Predicted exposure: wind direction $=$ $40^{\circ}$; inflection $=6^{\circ}$.

of the total area classified as protected differed from section to section, reflecting differences in underlying topography (Fig. 12). In each case, as the inflection angle increased, the percentage of the total area classified as protected decreased, as did the average damage sustained in those protected areas.

The association between predicted protected areas for different wind directions and low actual damage varied across the study area (Fig. 13). Over the entire study area it was highest for a $0^{\circ}$ wind. In the west and east sections it was highest for a $330^{\circ}$ wind; in the east there was a secondary peak at $50^{\circ}$. In the central section there was strong association with winds from $0^{\circ}$ to $40^{\circ}$, with a peak at $10^{\circ}$. The two peaks in the east section were close to the two peak treefall orientations in the Eastern LEF study area $\left(\approx 315^{\circ}\right.$ and $45^{\circ}$; see below). Associations in all sections were consistent with a peak wind from $340^{\circ}$ as predicted by HURRECON and local channelling of the wind up the Rio Mameyes valley, causing local winds from the northeast in portions of the east section and much of the central section.

Across the entire LEF, large portions of the rugged mountain landscape were classified as protected (Fig. 14). As predicted, actual damage was largely confined to the north-facing slopes.

Broad-scale damage patterns. - The distribution of land area among the forest damage classes in the Northern LEF study area was highly uneven (Fig. 15, Table 4). Damage in classes $2(1-9 \%)$ and $3(10-39 \%)$ occupied $47 \%$ and $28 \%$ of the study area, respectively. Class $4(40-74 \%)$ occupied $14 \%$, whereas undamaged areas (class 1) and destroyed areas (class 5) each occupied $6 \%$ of the forest. The east-to-west damage gradient across the study area was striking: class 5 areas were restricted to the northeast section, class 4 damage was concentrated in the eastern half, class 2 and 3 

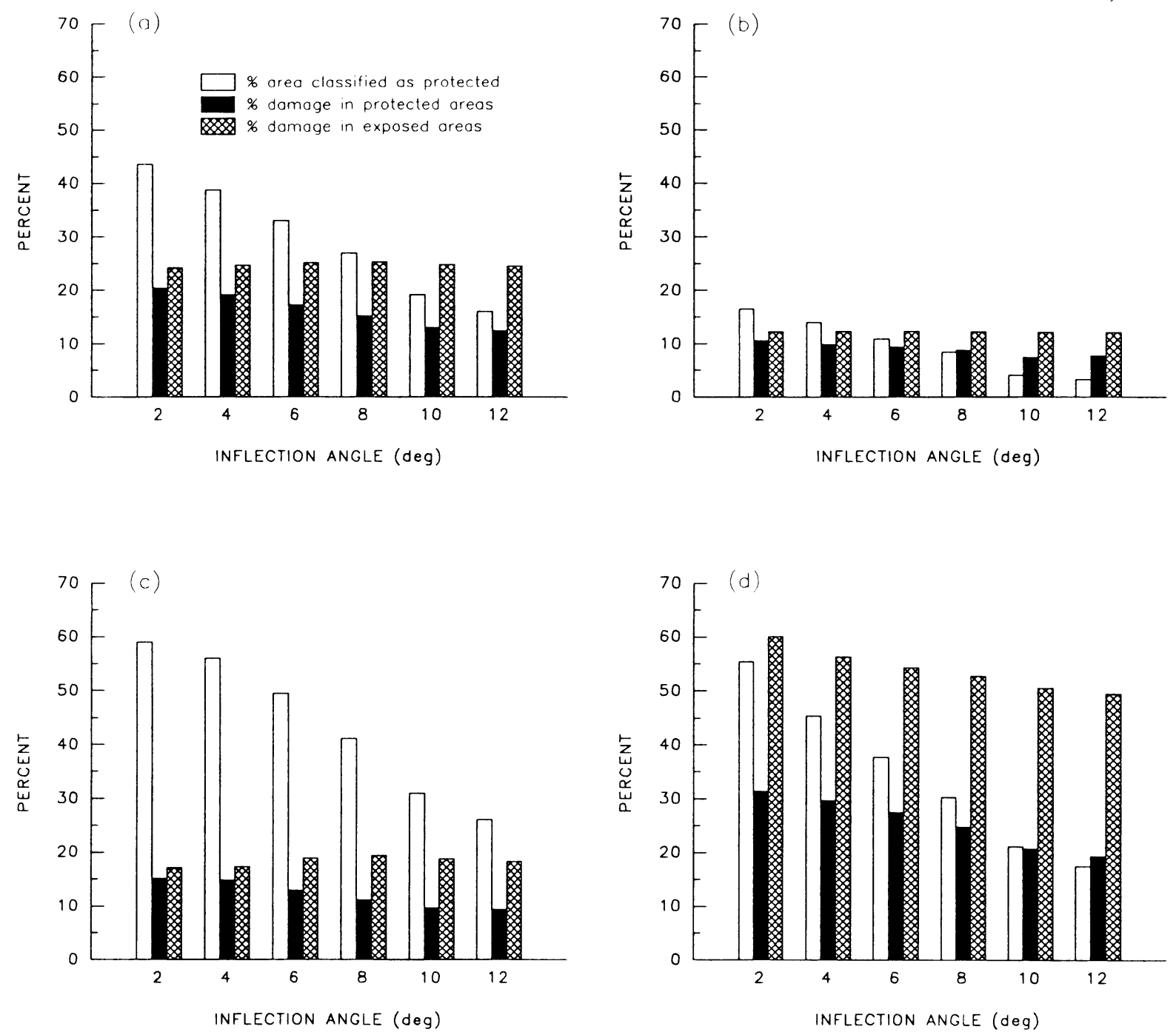

FIG. 12. Forest damage from Hurricane Hugo and predicted exposure for different sections of the Northern LEF study area and different inflection angles. Wind direction $=340^{\circ}$. (a) Entire study area. (b) West section. (c) Central section. (d) East section.

damage increased in the western two-thirds of the region, and undamaged areas fell along a general northeast-to-southwest line across the middle and western part of the study area.

Variation in the damage pattern coincided with major physiographic features (Fig. 15). For example, undamaged areas were concentrated on the southern to southeastern crests of ridges, and sharp discontinuities in damage coincided with ridgelines and associated changes in aspect orientation. Each damage class also exhibited a unique spatial pattern. Completely windthrown areas (class 5) were grouped together rather tightly in north-to-south linear patterns, and may have been the tracks of intense convective cells associated with the eyewall before the storm weakened. Class 4 damage was spread somewhat more, whereas class 3 and 2 areas covered broad contiguous areas in the west and rather more discontinuous regions in the east. Undamaged areas were extremely discontinuous and small.

Damage was strongly associated with differences in elevation and vegetation type (Tables 5 and 6). Completely damaged areas were concentrated between 100 and $400 \mathrm{~m}$ elevation and were confined to the tabonuco zone. Class 4 damage occurred predominantly in tabonuco forest below $600 \mathrm{~m}$. Classes 1, 2, and 3 extended across nearly the entire elevational range in all vegetation types, and in general were positively associated with colorado, palm, and dwarf forest types. In general there appeared to be an increase in damage with elevation at lower elevations (100-600 m) and a decrease at the highest elevations. The former may have been due to an increase in wind speed with elevation that caused greater damage among the broadleaved trees in the tabonuco forest, while at higher 

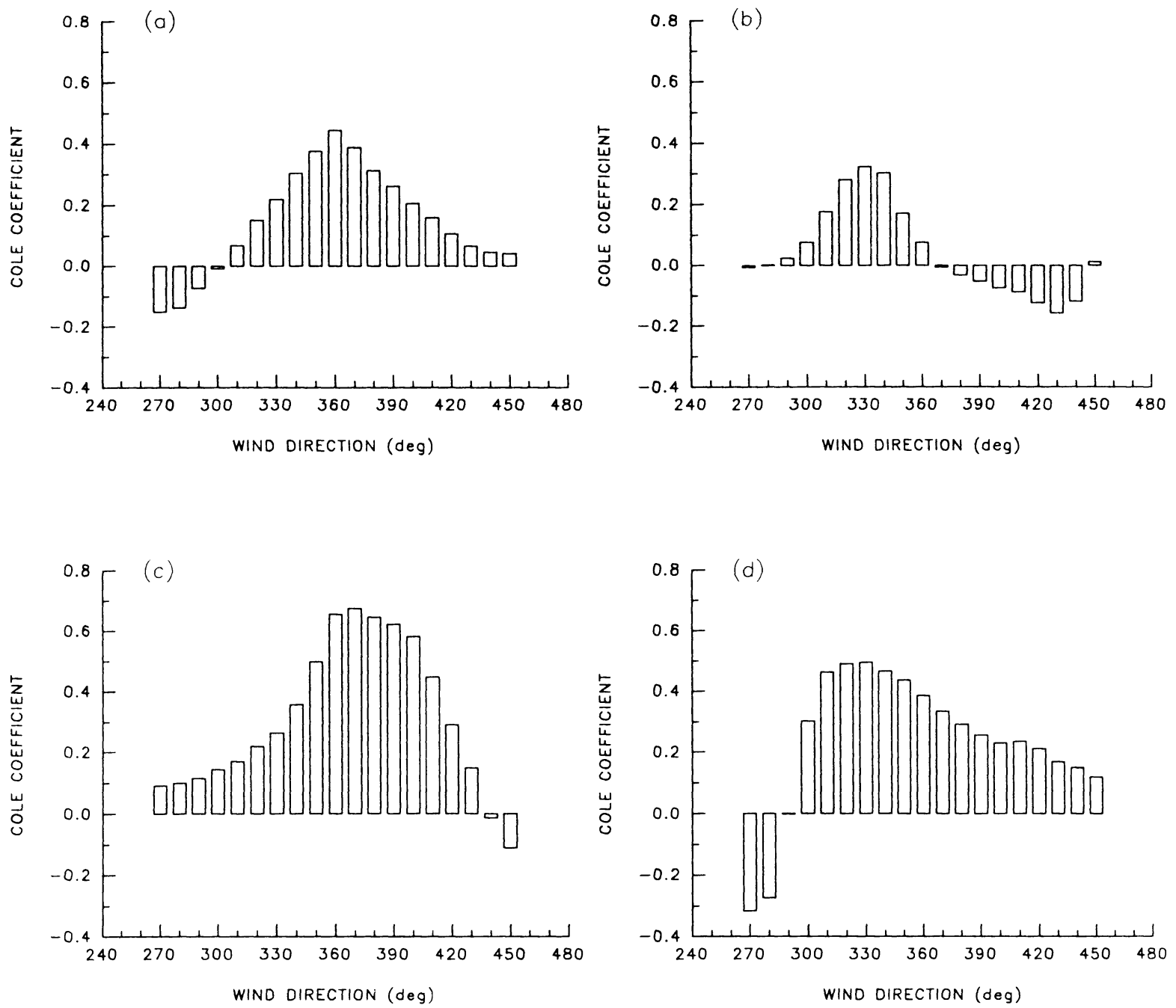

Fig. 13. Association between low forest damage ( $<10 \%$ windthrow) and predicted protected areas for different sections of the Northern LEF study area and different wind directions. Inflection angle $=6^{\circ}$. Measure of association is Cole's coefficient $(-1=$ maximum disassociation, $0=$ no association, $1=$ maximum association; Cole 1949). (a) Entire study area. (b) West section. (c) Central section. (d) East section.

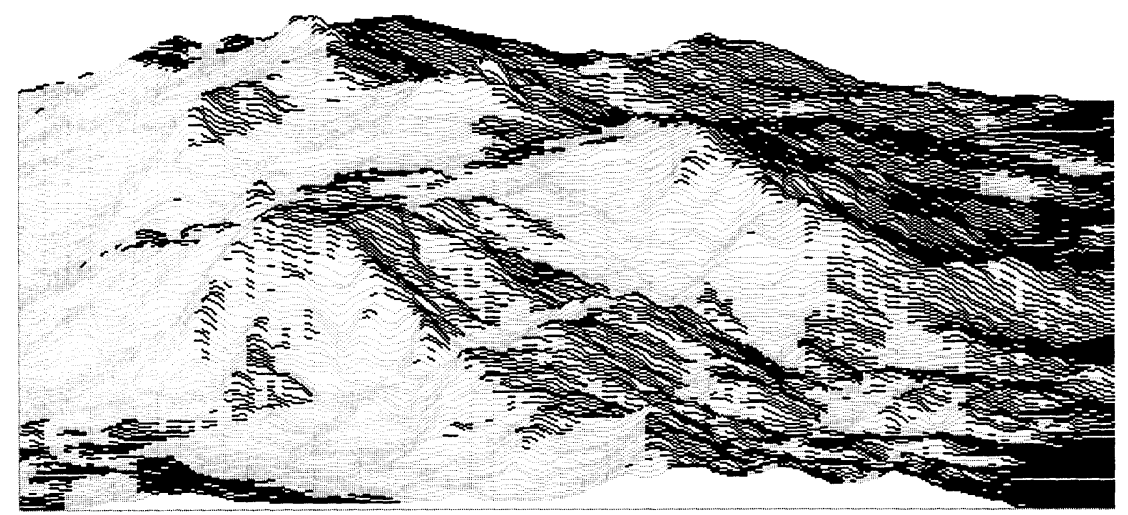

FIG. 14. Predicted exposure in the Luquillo Experimental Forest (light $=$ protected, dark $=$ exposed). The view is toward the west. Wind direction $=340^{\circ}$; inflection angle $=6^{\circ}$. 
TABLE 4. Characteristics of the Northern LEF study area.

\begin{tabular}{|c|c|c|c|c|c|c|c|c|c|}
\hline \multirow{2}{*}{\multicolumn{2}{|c|}{ Category }} & \multicolumn{2}{|c|}{ Entire area } & \multicolumn{2}{|c|}{ West section } & \multicolumn{2}{|c|}{ Central section } & \multicolumn{2}{|c|}{ East section } \\
\hline & & (ha) & $(\%)$ & (ha) & $(\%)$ & (ha) & $(\%)$ & (ha) & $(\%)$ \\
\hline \multicolumn{10}{|c|}{ (a) Elevation (m) } \\
\hline & 0-99 & 7 & 0 & 7 & 0 & 0 & 0 & 0 & 0 \\
\hline & $100-199$ & 341 & 7 & 117 & 7 & 32 & 2 & 191 & 13 \\
\hline & $200-299$ & 581 & 11 & 146 & 8 & 111 & 6 & 324 & 22 \\
\hline & $300-399$ & 714 & 14 & 179 & 10 & 225 & 11 & 311 & 21 \\
\hline & $400-499$ & 850 & 16 & 223 & 13 & 333 & 17 & 295 & 20 \\
\hline & $500-599$ & 848 & 16 & 271 & 15 & 294 & 15 & 282 & 19 \\
\hline & $600-699$ & 649 & 12 & 237 & 13 & 333 & 17 & 78 & 5 \\
\hline & $700-799$ & 705 & 13 & 355 & 20 & 350 & 18 & 0 & 0 \\
\hline & $800-899$ & 412 & 8 & 221 & 12 & 191 & 10 & 0 & 0 \\
\hline & $900-999$ & 131 & 3 & 24 & 1 & 106 & 5 & 0 & 0 \\
\hline & $1000-1099$ & 17 & 0 & 0 & 0 & 17 & 1 & 0 & 0 \\
\hline \multicolumn{10}{|c|}{ (b) Forest type } \\
\hline & Secondary & 26 & 1 & 26 & 2 & 0 & 0 & 0 & 0 \\
\hline & Tabonuco & 2720 & 52 & 679 & 38 & 701 & 35 & 1340 & 90 \\
\hline & Colorado & 1459 & 28 & 832 & 47 & 495 & 25 & 132 & 9 \\
\hline & Palm & 929 & 18 & 232 & 13 & 687 & 35 & 9 & 1 \\
\hline & Dwarf & 119 & 2 & 11 & 1 & 109 & 6 & 0 & 0 \\
\hline \multicolumn{10}{|c|}{ (c) Aspect } \\
\hline & South & 239 & 5 & 41 & 2 & 110 & 6 & 88 & 6 \\
\hline & Southwest & 312 & 6 & 103 & 6 & 117 & 6 & 92 & 6 \\
\hline & West & 490 & 9 & 287 & 16 & 96 & 5 & 107 & 7 \\
\hline & Northwest & 945 & 18 & 577 & 32 & 195 & 10 & 173 & 12 \\
\hline & North & 1328 & 25 & 488 & 27 & 504 & 25 & 335 & 23 \\
\hline & Northeast & 921 & 18 & 190 & 11 & 382 & 19 & 349 & 24 \\
\hline & East & 543 & 10 & 27 & 2 & 328 & 17 & 188 & 13 \\
\hline & Southeast & 387 & 7 & 25 & 1 & 231 & 12 & 130 & 9 \\
\hline & Level & 89 & 2 & 43 & 2 & 28 & 1 & 18 & 1 \\
\hline \multicolumn{10}{|c|}{ (d) Hurricane damage } \\
\hline & Undamaged & 298 & 6 & 120 & 7 & 177 & 9 & 1 & 0 \\
\hline & Slight & 2451 & 47 & 1012 & 57 & 1010 & 51 & 429 & 29 \\
\hline & Moderate & 1453 & 28 & 649 & 37 & 604 & 30 & 201 & 14 \\
\hline & Very & 750 & 14 & 0 & 0 & 202 & 10 & 548 & 37 \\
\hline & Destroyed & 302 & 6 & 0 & 0 & 0 & 0 & 302 & 20 \\
\hline
\end{tabular}

elevations the forest canopy decreases in stature, eventually becoming a dense, scrubby dwarf forest that was more root firm and tended to suffer defoliation rather than windthrow (cf. Howard 1968, Weaver 1986).

Interpretation of these results was complicated by the strong east-to-west damage gradient. The range of damage to low-elevation tabonuco forest on north-facing slopes along the northern edge of the study area suggested that the meteorological gradient was the most important factor in determining the location of forest damage. The eastern section, which sustained most of the class 4 and all of the class 5 damage, was almost entirely lower elevation tabonuco forest.

The relationship between aspect and damage was relatively consistent (Table 7). Over the entire study area, the greatest damage (classes 4 and 5) was associated with northwest to east slopes. Class 3 damage was associated with west to north slopes, whereas damage in classes 1 and 2 was more evenly spread but was positively associated with east to south to west aspects. In the east section, where the greatest damage occurred, the strength of association between destroyed forest and northwest and north slopes increased greatly, while classes 1 and 2 exhibited stronger association with east to southwest slopes.

Treefall orientation. - In the Eastern LEF study area, wind directions for 2598 wind-thrown trees ranged from $181^{\circ}$ clockwise to $97^{\circ}$, with a concentration from $280^{\circ}$ to $90^{\circ}$ (Fig. 16). Approximately $61 \%$ of the stem orientations indicated winds from the northwest quadrant $\left(270^{\circ}\right.$ to $\left.0^{\circ}\right), 29 \%$ from the northeast quadrant $\left(0^{\circ}\right.$ to $\left.90^{\circ}\right), 9 \%$ from the southwest quadrant $\left(180^{\circ}\right.$ to $\left.270^{\circ}\right)$, and $1 \%$ from the southeast quadrant $\left(90^{\circ}\right.$ to $\left.180^{\circ}\right)$. There was a slight low in the distribution around $10^{\circ}$. In the area to the southeast of the Rio del Cristal ( $n=$ 2082 ) the breakdown between northwest and northeast winds was $64 \%$ and $25 \%$, respectively, with a slight trough around $10^{\circ}$. To the northwest $(n=516)$, closer to the Rio Mameyes valley, there was a much larger component from the northeast: $47 \%$ from the northwest, $48 \%$ from the northeast, and a pronounced trough around $0^{\circ}$.

At $\mathrm{El}$ Verde the average wind direction for 1712 severely damaged trunks was $340^{\circ}$; the distribution was fairly symmetrical around a pronounced peak at $350^{\circ}$ (Fig. 16). Approximately $40 \%$ of the treefall orienta- 
(a)

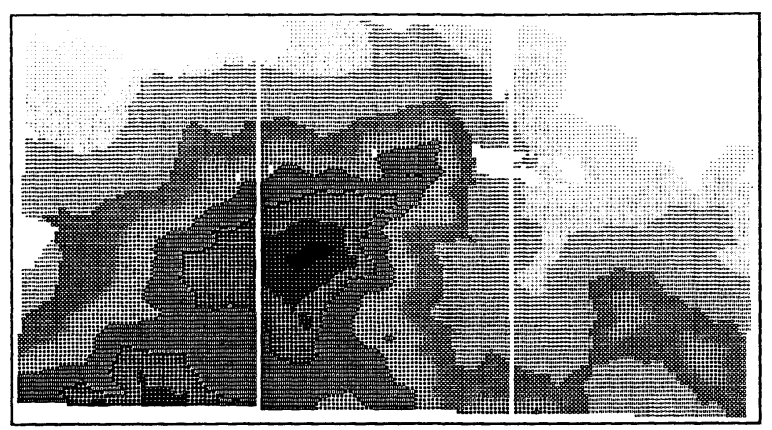

(b)

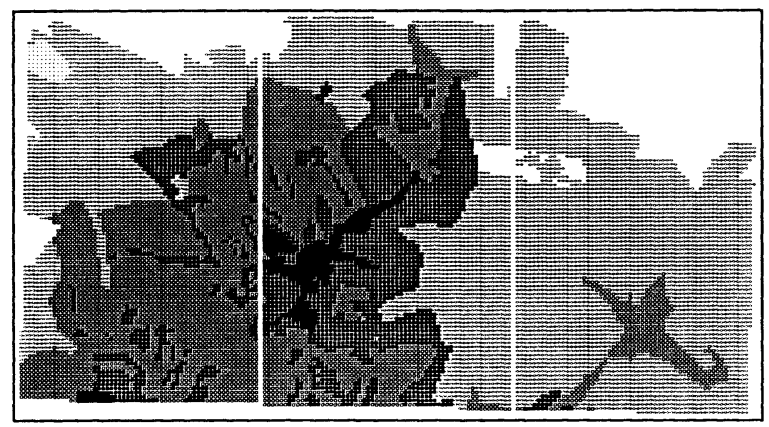

(c)

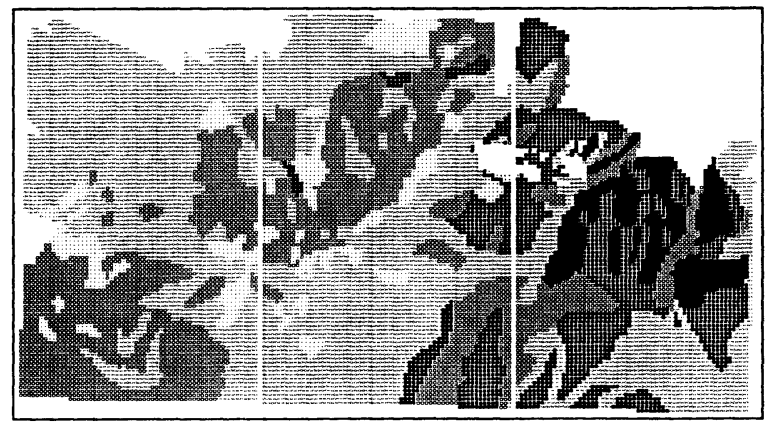

50-99 m

100-199 m

200-299 m

300-399 m

400-499 m

500-599 m

600-699 m

700-799 m

$800-899 \mathrm{~m}$

900-999 m

1000-1035 m
Secondary
Tabonuco
Colorado
Palm
Dwarf

Fig. 15. Northern LEF study area, showing (left to right) west, central, and east sections. (a) Elevation in 100-m contours. (b) Major forest types (USDA Forest Service, unpublished data). (c) Forest damage from Hurricane Hugo in five severity classes. Values indicate estimated percentage of wind-thrown trees.

tions indicated winds from the northwest quadrant, $28 \%$ from the northeast quadrant, $20 \%$ from the southwest quadrant, and $12 \%$ from the southeast quadrant.

The HURRECON model predicted little variation in the direction of the peak sustained wind in the LEF because of proximity to the storm track. However a wide variation in treefall orientation was observed at El Verde and in the 108 individual areas in the Eastern LEF study area, suggesting considerable air turbulence and variation in wind gust direction, presumably because of the rugged terrain. There was also a wide variation in peak treefall orientation from one area to another, and some evidence of topographic control of wind direction, including apparent wind deflection around local peaks and wind channelling along river valleys (especially the Rio Mameyes; Fig. 17). It is possible that local topography further increased the variance in treefall orientation by influencing the fall and secondary movement of wind-thrown trees on the steepest slopes.

\section{Hurricane}

Meteorological reconstruction. - Wind velocity data from Providence were used to set the value of the wind profile constant $X$ and therefore did not provide an independent check of the model. However after cali- 
TABLE 5. Relationship between hurricane damage and elevation in the Northern LEF study area. Values are Cole's coefficient for positive association.

\begin{tabular}{|c|c|c|c|c|c|c|c|c|c|c|c|c|}
\hline \multirow{2}{*}{\multicolumn{2}{|c|}{ Damage class }} & \multicolumn{11}{|c|}{ Elevation (m) } \\
\hline & & $\begin{array}{l}0- \\
99\end{array}$ & $\begin{array}{r}100- \\
199\end{array}$ & $\begin{array}{r}200- \\
299\end{array}$ & $\begin{array}{r}300- \\
399\end{array}$ & $\begin{array}{r}400- \\
499\end{array}$ & $\begin{array}{r}500- \\
599\end{array}$ & $\begin{array}{r}600- \\
699\end{array}$ & $\begin{array}{r}700- \\
799\end{array}$ & $\begin{array}{r}800- \\
899\end{array}$ & $\begin{array}{r}900- \\
999\end{array}$ & $\begin{array}{r}1000 \\
1099\end{array}$ \\
\hline \multicolumn{13}{|c|}{ (a) Entire area } \\
\hline & Undamaged & & & & & & 0.02 & & 0.04 & 0.12 & 0.11 & 0.36 \\
\hline & Slight & 1.00 & 0.13 & 0.15 & & & & & 0.15 & & & \\
\hline & Moderate & & & & & & 0.03 & 0.17 & 0.12 & 0.24 & 0.28 & 0.43 \\
\hline & Very & & 0.06 & 0.08 & 0.05 & 0.08 & 0.08 & & & & & \\
\hline & Destroyed & & 0.09 & 0.22 & 0.26 & & & & & & & \\
\hline \multirow{5}{*}{ (b) } & West section & & & & & & & & & & & \\
\hline & Undamaged & & & & & 0.11 & 0.28 & & & 0.14 & & \\
\hline & $\begin{array}{l}\text { Slight } \\
\text { Moderate }\end{array}$ & 1.00 & 1.00 & 1.00 & 1.00 & & 007 & 054 & 028 & 024 & 066 & \\
\hline & Very & & & & & & & & & & 0.00 & \\
\hline & Destroyed & & & & & & & & & & & \\
\hline \multirow{6}{*}{ (c) } & Central section & & & & & & & & & & & \\
\hline & Undamaged & & & & 0.12 & & & & 0.07 & 0.06 & 0.10 & 0.34 \\
\hline & Slight & & 0.35 & 0.52 & & & & 0.18 & 0.31 & & & \\
\hline & Moderate & & 0.02 & & & 0.15 & 0.11 & & & 0.11 & 0.16 & 0.41 \\
\hline & Very & & & & 0.07 & 0.19 & 0.16 & & & & & \\
\hline & Destroyed & & & & & & & & & & & \\
\hline \multirow{6}{*}{ (d) } & East section & & & & & & & & & & & \\
\hline & Undamaged & & & & 1.00 & & & & & & & \\
\hline & Slight & & & & & 0.09 & 0.23 & 0.17 & & & & \\
\hline & Moderate & & 0.06 & & 0.16 & 0.02 & & & & & & \\
\hline & Very & & & & & & 0.05 & 0.34 & & & & \\
\hline & Destroyed & & 0.05 & 0.11 & 0.19 & & & & 1.00 & & & \\
\hline
\end{tabular}

bration the observed and predicted sustained wind speeds at Providence did agree generally to within 5 $\mathrm{m} / \mathrm{s}$ (Fig. 18). Wind direction data at Providence, not used to calibrate the model, showed that the observed and predicted wind directions differed widely as the storm first approached (while wind speeds were still low) but agreed generally to within $20^{\circ}$ during and after the height of the storm (Fig. 18). The actual inflow angle at Providence during the height of the storm averaged $25^{\circ}$ (Table 2 ).

Comparisons of observed and predicted wind conditions at three sites from east to west across the storm track showed that the predicted sustained wind speed was generally within $5 \mathrm{~m} / \mathrm{s}$ of the observed value (Fig. 19). The match was best during the height of the storm at Block Island and Hartford; both predicted and observed wind speeds were lower at Poughkeepsie, to the west of the storm track. Observed and predicted wind directions were widely different during the early part of the storm (while wind speeds were still low) at Block Island and Hartford. However during and after the height of the storm at these locations, and for the entire period at Poughkeepsie, predicted and observed values agreed generally to within $20^{\circ}$ (Fig. 19). Actual inflow angles during the height of the storm averaged $27^{\circ}$ at Block Island, $25^{\circ}$ at Hartford, and $43^{\circ}$ at Poughkeepsie (Table 2).

Regional reconstructions of wind conditions suggested that, because of the exceptional forward velocity of this hurricane, high winds were concentrated on the eastern side of the storm track (Fig. 20). The area of predicted maximum gust velocity extended northward along a broad swath through central New England, gradually decreasing in intensity as the storm weakened over land. These predictions closely matched the map of regional forest damage, especially in southern and central New England (NETSA 1943; Fig. 21). The greatest damage was concentrated in a band from northern Connecticut and Rhode Island through central New Hampshire. This band coincided with the intersection of the area of highest predicted winds and areas where white pine was abundant in 1938 (Baldwin 1942); white pine has been shown to be particularly susceptible to wind damage (Foster 1988a). In northern New England the greatest damage was located somewhat farther to the east of the storm track than the model predicted, suggesting the expansion of the ring of maximum winds that normally occurs as a hurricane finally expires (see Discussion: Regional scale, below).

From east to west across the town of Petersham only small differences in peak wind speed $(4 \mathrm{~m} / \mathrm{s})$ and direction $\left(1^{\circ}\right)$ were predicted, because Petersham was beyond the range of the eyewall and the steepest wind gradients and because the storm weakened only slightly during the period of impact. No evidence of a broadscale gradient of forest damage across Petersham was found (Harvard Forest Archives, unpublished data).

Predicted peak wind velocity and direction at Harvard Forest and Pisgah Forest were compared with 
TABLE 6. Relationship between hurricane damage and forest type in the Northern LEF study area. Values are Cole's coefficient for positive association.

\begin{tabular}{|c|c|c|c|c|c|c|}
\hline \multirow{2}{*}{\multicolumn{2}{|c|}{ Damage class }} & \multicolumn{5}{|c|}{ Forest type } \\
\hline & & $\begin{array}{l}\text { Second- } \\
\text { ary }\end{array}$ & $\begin{array}{l}\text { Tabo- } \\
\text { nuco }\end{array}$ & $\begin{array}{l}\text { Colo- } \\
\text { rado }\end{array}$ & Palm & Dwarf \\
\hline \multicolumn{7}{|c|}{ (a) Entire area } \\
\hline & Undamaged & \multirow{5}{*}{1.00} & & \multirow[t]{2}{*}{0.20} & \multirow{2}{*}{$\begin{array}{l}0.03 \\
0.21\end{array}$} & 0.23 \\
\hline & Slight & & & & & \\
\hline & Moderate & & & \multirow{3}{*}{0.21} & \multirow{3}{*}{0.07} & 0.18 \\
\hline & Very & & 0.71 & & & \\
\hline & Destroyed & & 1.00 & & & \\
\hline \multirow[t]{5}{*}{ (b) } & West section & \multirow{5}{*}{1.00} & & \multirow[b]{2}{*}{0.31} & \multirow{5}{*}{0.16} & \multirow{5}{*}{0.88} \\
\hline & Undamaged & & & & & \\
\hline & Slight & & 0.61 & \multirow{3}{*}{0.41} & & \\
\hline & $\begin{array}{l}\text { Moderate } \\
\text { Very }\end{array}$ & & & & & \\
\hline & Destroyed & & & & & \\
\hline \multirow[t]{6}{*}{ (c) } & Central section & & & & & \\
\hline & Undamaged & & & 0.04 & \multirow{5}{*}{0.21} & 0.23 \\
\hline & Slight & & & & & \\
\hline & Moderate & & & 0.06 & & 0.08 \\
\hline & Very & & 0.54 & & & \\
\hline & Destroyed & & & & & \\
\hline \multirow[t]{6}{*}{ (d) } & East section & & & \multirow{6}{*}{0.42} & \multirow{4}{*}{0.29} & \\
\hline & Undamaged & & 1.00 & & & \\
\hline & Slight & & & & & \\
\hline & Moderate & & 0.31 & & & \\
\hline & Very & & 0.12 & & \multirow[t]{2}{*}{0.21} & \\
\hline & Destroyed & & 0.99 & & & \\
\hline
\end{tabular}

damage at the two sites (Table 8). Harvard Forest was located $\approx 63 \mathrm{~km}$ from the storm track and thus beyond the predicted range of the eyewall (eye radius $=46$ $\mathrm{km})$. Accordingly the model predicted a single peak from the southeast $\left(135^{\circ}\right)$. Pisgah Forest $(37 \mathrm{~km}$ to the northwest) was located $\approx 43 \mathrm{~km}$ from the storm track, and thus within range of the eastern eyewall. As a result two peaks were predicted: the first $\approx 20^{\circ}$ closer to east and the second $\approx 20^{\circ}$ closer to south than at Harvard Forest.

Analysis of wind-thrown trees at Harvard Forest showed an average wind direction of $124^{\circ}, 11^{\circ}$ to the east of the predicted peak wind direction and within the likely accuracy of the model. The asymmetrical shape of the treefall vs. orientation graph suggests that a majority of trees were felled before the peak treefall at $135^{\circ}$ (the predicted peak wind direction), and perhaps before the winds reached their peak velocity (Fig. 22). Analysis of conifer windthrow at the Harvard Forest showed that the average orientation angle for taller conifer stands $(\geq 15 \mathrm{~m})$ was $11^{\circ}$ to the east of the average for shorter conifer stands $(<15 \mathrm{~m})$, and the difference was statistically significant using a two-sample $t$ test $(P=0.002$; Fig. 22$)$. Taller trees are more susceptible to windthrow (Foster 1988a, Foster and Boose 1992) and therefore might have fallen earlier in the storm and at lower wind velocities than shorter trees.

Treefall data from Pisgah Forest showed an average wind direction of $105^{\circ}, 11^{\circ}$ to the east of the predicted first peak and within the likely accuracy of the model (Fig. 23). The close agreement between the average

TABLE 7. Relationship between hurricane damage and aspect in the Northern LEF study area. Values are Cole's coefficient for positive association.

\begin{tabular}{|c|c|c|c|c|c|c|c|c|c|c|}
\hline & \multirow[b]{2}{*}{ Damage class } & \multicolumn{9}{|c|}{ Aspect } \\
\hline & & $\mathrm{S}$ & SW & W & NW & $\mathbf{N}$ & $\mathrm{NE}$ & $\mathrm{E}$ & $\mathrm{SE}$ & Level \\
\hline \multirow{6}{*}{ (a) } & Entire area & & & & & & & & & \\
\hline & Undamaged & 0.04 & 0.03 & 0.03 & & & & 0.01 & 0.07 & 0.04 \\
\hline & Slight & 0.51 & 0.42 & & & & & 0.03 & 0.39 & 0.23 \\
\hline & Moderate & & & 0.13 & 0.11 & 0.08 & & & & \\
\hline & Very & & & & & 0.03 & 0.12 & 0.10 & & \\
\hline & Destroyed & & & & 0.15 & 0.17 & & & & \\
\hline \multirow[t]{5}{*}{ (b) } & West section & & & & & & & & & \\
\hline & Undamaged & 0.19 & 0.01 & & & & & 0.01 & 0.31 & 0.12 \\
\hline & Slight & 0.08 & 0.18 & & & 0.03 & 0.16 & & & 0.15 \\
\hline & Moderate & & & 0.08 & 0.04 & 0.01 & & 0.41 & & \\
\hline & Destroyed & & & & & & & & & \\
\hline \multirow[t]{5}{*}{ (c) } & Central section & & & & & & & & & \\
\hline & Undamaged & 0.02 & 0.06 & 0.11 & & & & 0.02 & 0.07 & \\
\hline & Slight & 0.55 & 0.37 & & & & & 0.17 & 0.54 & 0.21 \\
\hline & Moderate & & & 0.01 & 0.32 & 0.25 & 0.06 & & & \\
\hline & $\begin{array}{l}\text { Very } \\
\text { Destroyed }\end{array}$ & & & & 0.04 & 0.03 & 0.08 & 0.06 & & 0.05 \\
\hline \multirow{6}{*}{ (d) } & East section & & & & & & & & & \\
\hline & Undamaged & & & & & & & 0.35 & 0.53 & \\
\hline & Slight & 0.64 & 0.63 & & & & & 0.04 & 0.36 & 0.23 \\
\hline & Moderate & & & 0.19 & & & 0.12 & 0.07 & & \\
\hline & Very & & & 0.01 & & 0.12 & 0.10 & 0.09 & & \\
\hline & Destroyed & & & & 0.40 & 0.20 & & & & \\
\hline
\end{tabular}



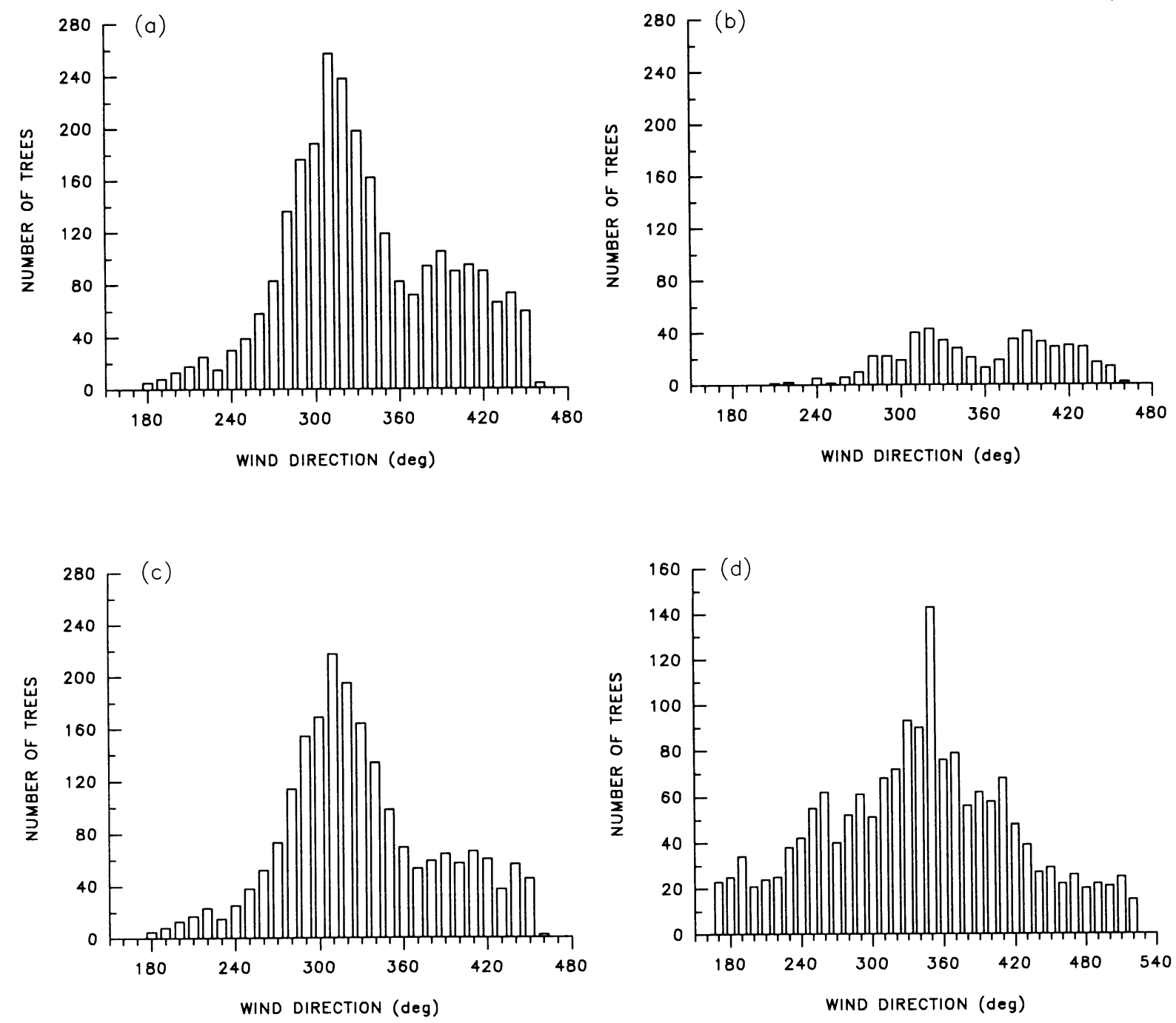

FIG. 16. Treefall orientation across the LEF during Hurricane Hugo, showing number of trees as a function of wind direction. (a) Eastern LEF study area $(n=2598)$. (b) Eastern LEF study area northwest of the Rio del Cristal $(n=516$; see Fig. 17). (c) Eastern LEF study area southeast of the Rio del Cristal $(n=2082)$. (d) El Verde 16-ha plot $(n=1712)$.

treefall orientation and the predicted first peak suggested that the majority of windthrows at Pisgah Forest occurred with the leading eyewall.

The HURRECON model predicted a fairly broad range in the direction of the highest sustained winds at Harvard Forest and Pisgah Forest because of the distance from these sites to the storm track. The relatively narrow range in actual treefall orientation at both sites was apparently the result of: (1) windthrow of a majority of trees at the first onset of catastrophic wind speeds, as discussed above, and (2) relatively little variation in wind gust direction, presumably because the gentle topography did not create severe air turbulence.

Topographic exposure. - In general, undamaged mature white pine stands in the town of Petersham were located in protected areas and those that were de- stroyed were located in exposed areas, using the southeast $\left(135^{\circ}\right)$ wind predicted by HURRECON and an inflection angle of $6^{\circ}$ to predict exposure (Fig. 24). The percentage of the study area classified as protected decreased rapidly as the inflection angle increased (Fig. 25). The percentage of both undamaged and destroyed stands occurring in protected areas also decreased as the inflection angle increased; however, for each inflection angle there was a large difference between the two, suggesting fairly good agreement between predicted exposure and actual damage. With an inflection angle of $6^{\circ}, 11 \%$ of the landscape was classified as protected, while $78 \%$ of the undamaged stands and only $5 \%$ of the destroyed stands were located in protected areas.

Most of this gently rolling landscape was classified as exposed, and protected areas were scattered and 


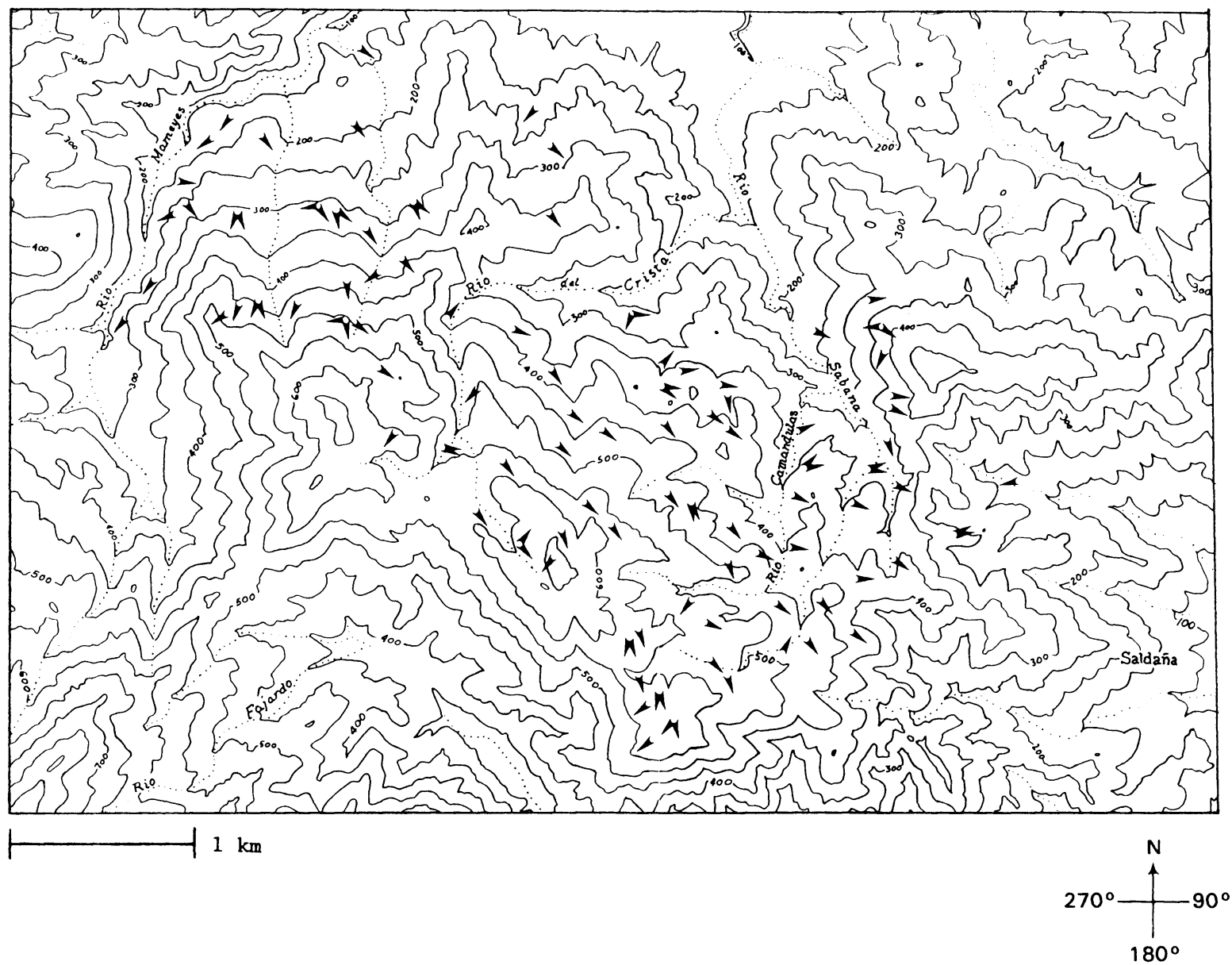

FIG. 17. Elevation in 50-m contours and treefall orientation across the Eastern LEF study area. Arrows show wind directions corresponding to peak treefall orientations in each of 108 physiographically defined areas.

small (Fig. 26). As predicted, forest damage was widespread across the entire landscape (Harvard Forest Archives, unpublished data).

\section{Discussion}

The patterns of damage resulting from hurricane impact on a forested landscape are complex and may appear random or indecipherable (Shaw 1983). Interacting factors that influence the spatial distribution and severity of damage include meteorological, physiographic, and biotic features and the effects of previous natural and human disturbance. Especially where local topography is complex and where there is incomplete knowledge of vegetation characteristics and disturbance history, the importance of these different factors may be quite difficult to unravel. However, simple models of hurricane meteorology and topographic exposure do provide useful estimates of broad-scale meteorological and topographic effects and can explain much of the broad-scale complexity in the patterns of forest damage. Where there is good knowledge of vegetation characteristics and response to wind distur- bance, it may be possible to predict the damage itself (Foster and Boose 1992).

The accuracy and sensitivity of the models used in this paper are considered below, and the roles of meteorological, topographic, and biotic factors in determining forest damage are discussed for a range of spatial scales: continental $(\approx 5000 \mathrm{~km})$, regional $(\approx 500$ $\mathrm{km})$, landscape $(\approx 10 \mathrm{~km})$, and stand $(\approx 1 \mathrm{~km})$.

\section{Meteorological model (HURRECON)}

HURRECON is based on empirical meteorological studies of many individual hurricanes. The model reconstructs broad-scale surface wind conditions by assuming that the structure of the surface wind field in all hurricanes can be described by simple equations whose parameters are adjusted for particular storms. The accuracy of the model rests on the extent to which this is true, and the relative importance of more-localized effects (such as intense convective cells) that the model cannot predict.

One way to test the model is to examine meteorological data not used to calibrate the model and com- 

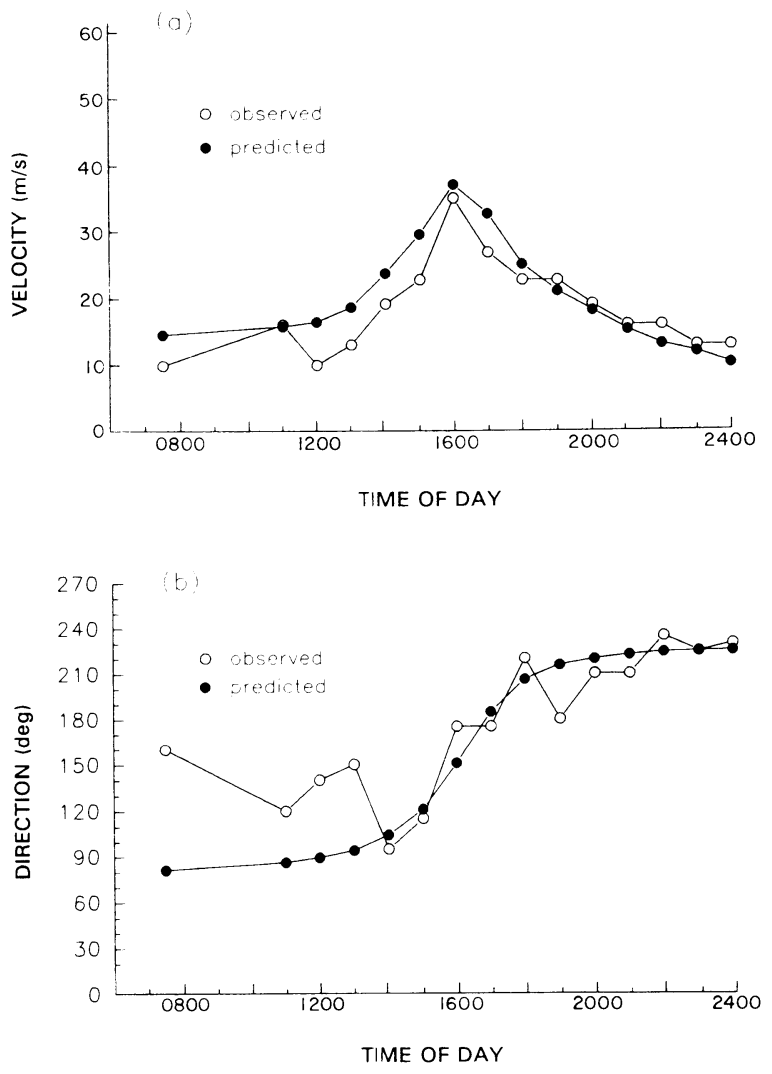

FIG. 18. Observed and predicted wind at Providence on 21 September 1938 during the 1938 New England Hurricane. (a) Sustained wind velocity and (b) sustained wind direction as a function of time of day (EST = Eastern Standard Time).

pare predicted and observed values. Our work to date with Hugo and the 1938 Hurricane, based on a limited number of sites (all urban airports), suggests that during the height of the storm (when winds are strong enough to impact forests) predicted sustained wind speeds are generally within $5 \mathrm{~m} / \mathrm{s}$ and predicted wind directions generally within $20^{\circ}$ of actual observed values for relatively flat unforested areas. Further use of the model should help to refine these figures.

A second way to test the model assumptions is to examine variation in the observed data. Analysis of observed inflow angles during the height of the storm in Hugo and the 1938 Hurricane, again based on a limited number of sites, showed an average standard deviation of $\approx 15^{\circ}$ (note that observed wind directions are normally rounded to the nearest $10^{\circ}$ ). If this figure is representative, then a margin of error of $\approx 20^{\circ}$ is probably as good as can be expected for model estimates of wind direction at specific times.

Spatial accuracy in estimated wind gradients is primarily a function of the error in determining the position and size of the eye. Track data from the National Hurricane Center for Hurricane Hugo were rounded to the nearest $0.1^{\circ}$ of latitude and longitude (roughly $\pm 5 \mathrm{~km})$. Eye measurements were recorded to the nearest nautical mile $(1.85 \mathrm{~km})$, but averaging major and minor axes for elliptical eyes introduced an error of up to $\approx 5 \mathrm{~km}$. Thus the margin of error in the predicted location of the eyewall was at least $5 \mathrm{~km}$ for Hugo. For older storms where track and eye data are less reliable the margin of error would be greater. Note that spatial accuracy is most critical near the left and right edges of the eye, where the steepest gradients (both actual and predicted) in peak wind speed occur.

\section{Topographic exposure model (EXPOS)}

The EXPOS model identifies points on a landscapescale topographic surface as exposed to or protected from a specified wind direction. The model roughly approximates the path in the vertical plane of the highest winds close to the ground. It does not estimate changes in wind speed or direction caused by the local topography.

The model is tested by comparing predicted exposure to actual landscape-level damage. The Northern Luquillo Experimental Forest (LEF) study area provided a complete and detailed data set for rugged mountainous terrain. The Petersham data, while incomplete, provided a test for gently rolling terrain. In both cases protected areas sustained significantly less damage than exposed areas over a range of inflection angles, using the peak wind direction predicted by the HURRECON model. Increasing the inflection angle caused the average damage in protected areas (and the extent of those areas) to decrease; thus a large inflection angle might be used to locate areas least likely to be impacted by winds from a given direction.

Comparison of actual damage and predicted exposure for different wind directions suggests that the model may be sensitive enough to indicate the direction of the damaging winds where topographic relief is significant and damage assessment is thorough. Results obtained in this way from the Northern LEF study area were consistent with the predicted peak wind direction and with the treefall orientation data.

\section{Continental scale}

The geographic and meteorological factors that control the formation and movement of hurricanes can only be understood on a continental scale $(\approx 5000 \mathrm{~km})$. The tendency for hurricanes to form in particular areas and follow general tracks is of great importance in determining the long-term hurricane disturbance regime for specific locations. Much is known, for example, about the tracks of hurricanes that have formed in the north Atlantic over the last 120 yr (Neumann et al. 1987). These data may be used to estimate the historical frequency of hurricanes affecting particular sites.

There are important differences between hurricanes in tropical and temperate regions. Hurricanes form over tropical oceans, and many never reach temperate latitudes. The ones that do tend to be less severe, for 

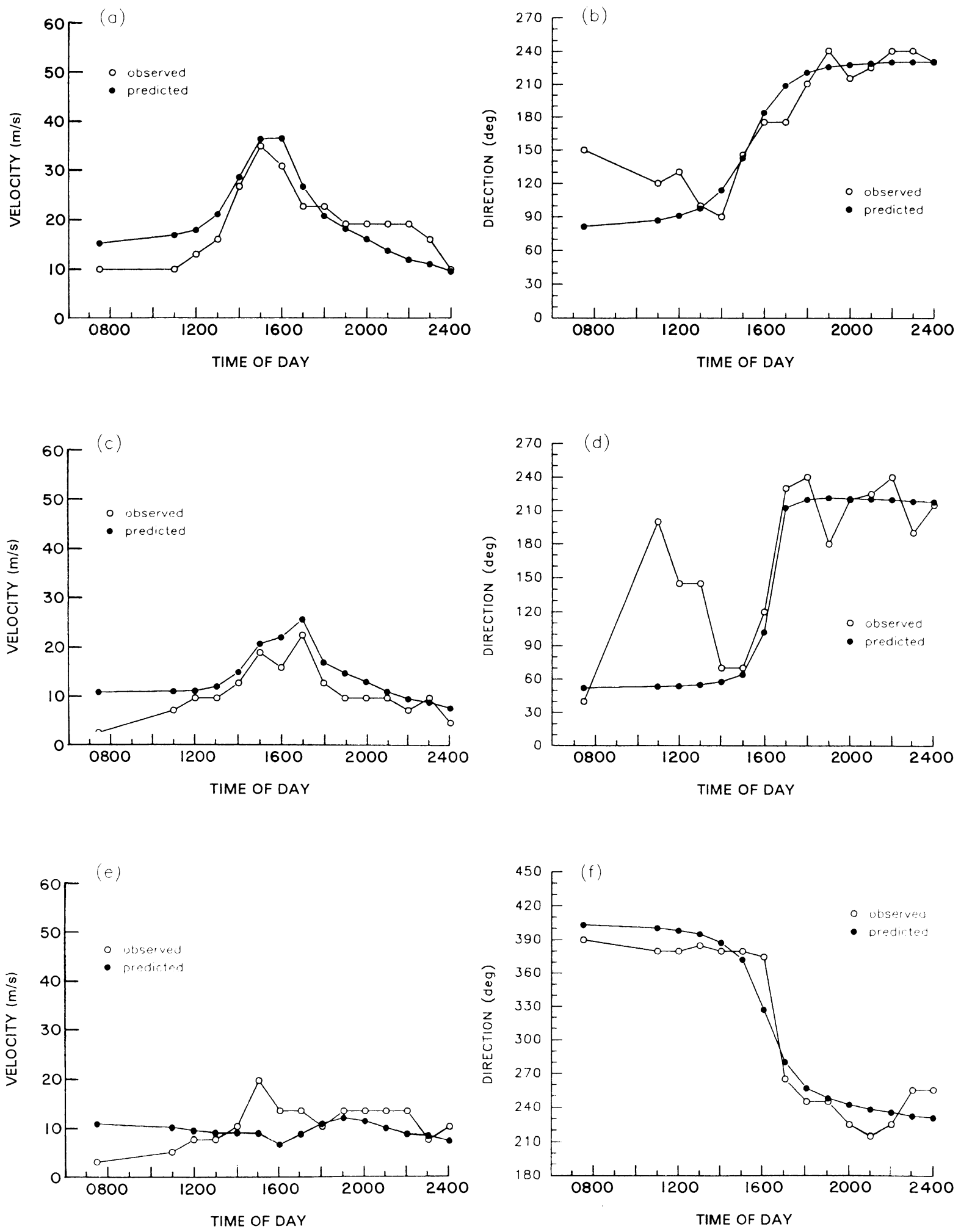

Fig. 19. Observed and predicted wind at three sites from east to west across the storm track on 21 September 1938 during the 1938 New England Hurricane. (Left side) Sustained wind velocity and (right side) sustained wind direction as a function of time of day (EST), for Block Island, Rhode Island (a and b), Hartford, Connecticut (c and d), and Poughkeepsie, New York (e and $f$ ). 
(a)

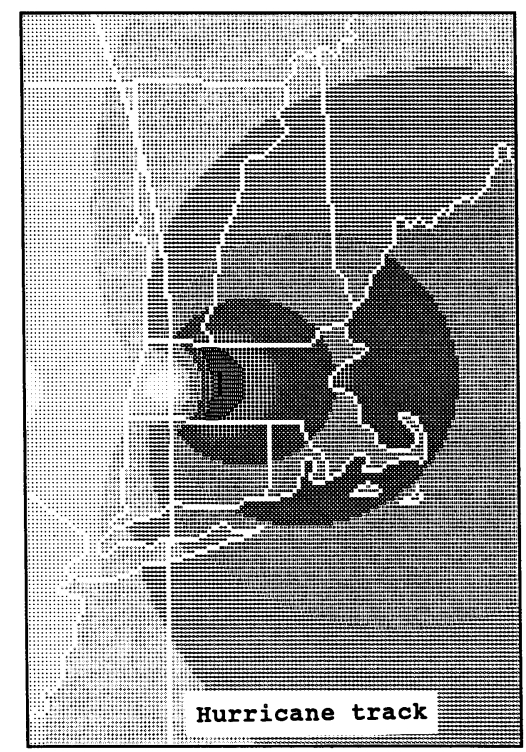

$\begin{array}{crcc} & \text { VELOCITY } & 21-26 \mathrm{~m} / \mathrm{s} \\ & 0-5 \mathrm{~m} / \mathrm{s} & 26-31 \mathrm{~m} / \mathrm{s} \\ 5-10 \mathrm{~m} / \mathrm{s} & 31-36 \mathrm{~m} / \mathrm{s} \\ 10-15 \mathrm{~m} / \mathrm{s} & 36-41 \mathrm{~m} / \mathrm{s} \\ 15-21 \mathrm{~m} / \mathrm{s} & 46 \mathrm{~m} / \mathrm{s}\end{array}$

(c)

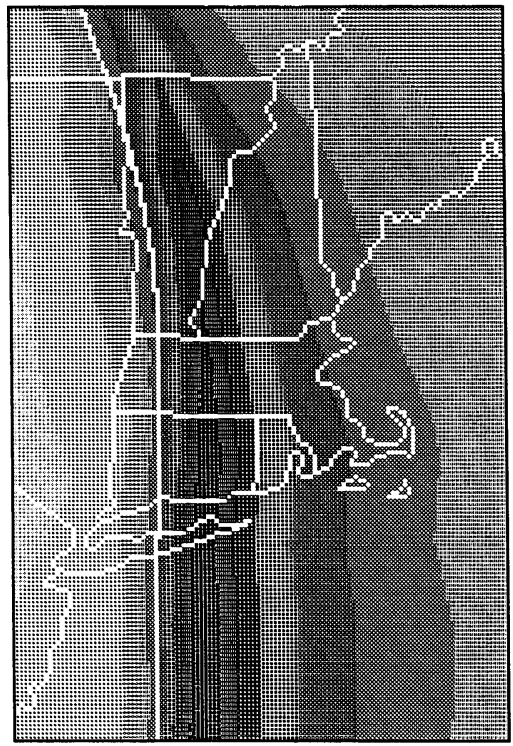

VELOCITY

0 - $5 \mathrm{~m} / \mathrm{s}$

$5-10 \mathrm{~m} / \mathrm{s}$
$10-15 \mathrm{~m} / \mathrm{s}$
$15-21 \mathrm{~m} / \mathrm{s}$

$5-10 \mathrm{~m} / \mathrm{s}$
$10-15 \mathrm{~m} / \mathrm{s}$
$15-21 \mathrm{~m} / \mathrm{s}$

$15-21 \mathrm{~m} / \mathrm{s}$
$21-26 \mathrm{~m} / \mathrm{s}$

$21-26 \mathrm{~m} / \mathrm{s}$
$26-31 \mathrm{~m} / \mathrm{s}$

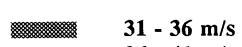

$36-41 \mathrm{~m} / \mathrm{s}$

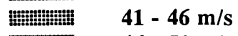
$46-51 \mathrm{~m} / \mathrm{s}$ $51-57 \mathrm{~m} / \mathrm{s}$ $57-62 \mathrm{~m} / \mathrm{s}$ (b)
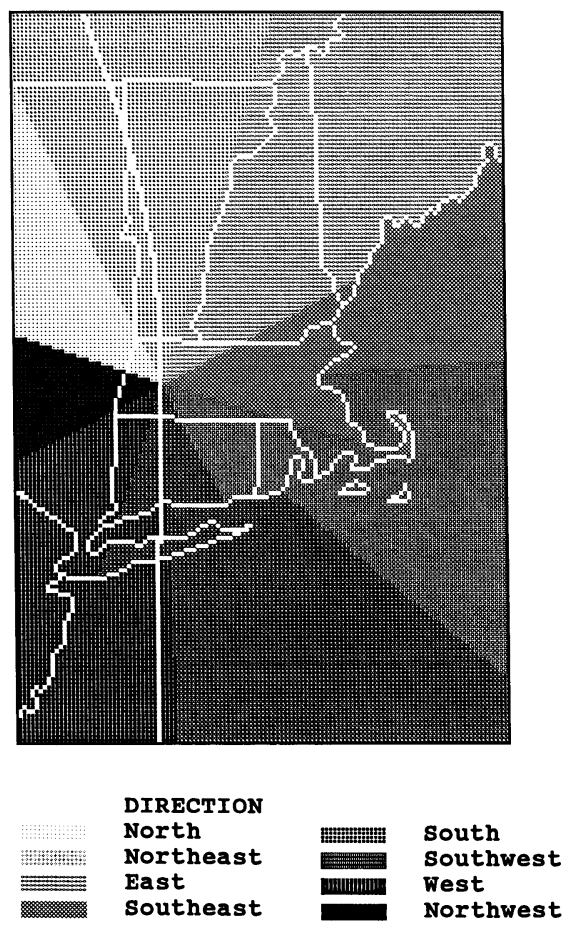

(d)

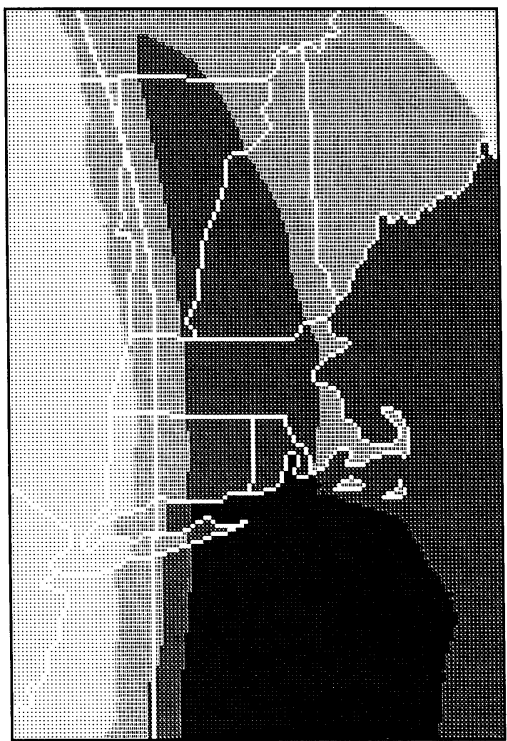

ENERGY

$0 \times 10^{-5}(\mathrm{~m} / \mathrm{s})^{2} \cdot \mathrm{h}$

$\quad<2.7 \times 10^{-5}(\mathrm{~m} / \mathrm{s})^{2} \cdot \mathrm{h}$

$2.7-5.3 \times 10^{-5}(\mathrm{~m} / \mathrm{s})^{2} \cdot$

$5.3-7.9 \times 10^{-5}(\mathrm{~m} / \mathrm{s})^{2} \cdot \mathrm{h}$

Fig. 20. Predicted wind over a $480 \times 720 \mathrm{~km}$ grid on 21 September during the 1938 New England Hurricane. Cell size $=4 \times 4 \mathrm{~km}$. (a) Predicted sustained wind velocity and (b) predicted sustained wind direction at 1700 EST. (c) Predicted maximum wind gust velocity and (d) predicted total energy of sustained winds of gale strength $(17 \mathrm{~m} / \mathrm{s})$ or greater over a 16.5-h period (time step $=2 \mathrm{~min}$ ) 
(a)

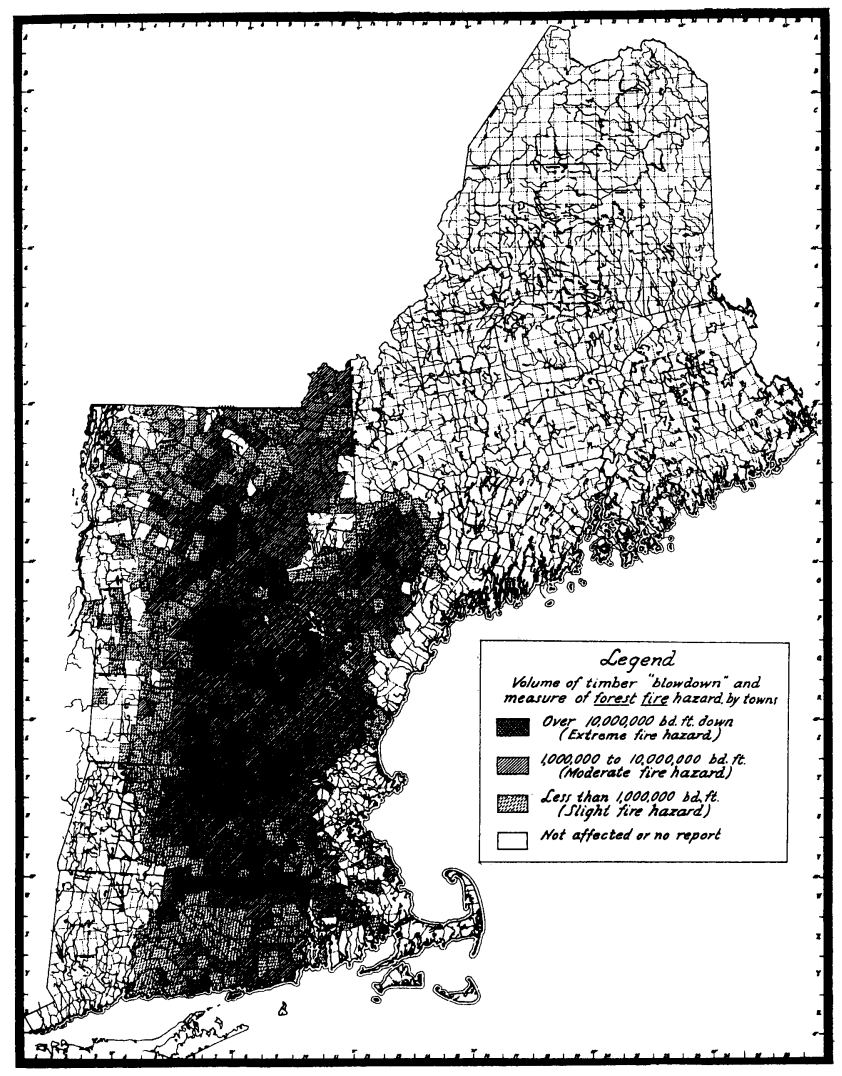

(b)
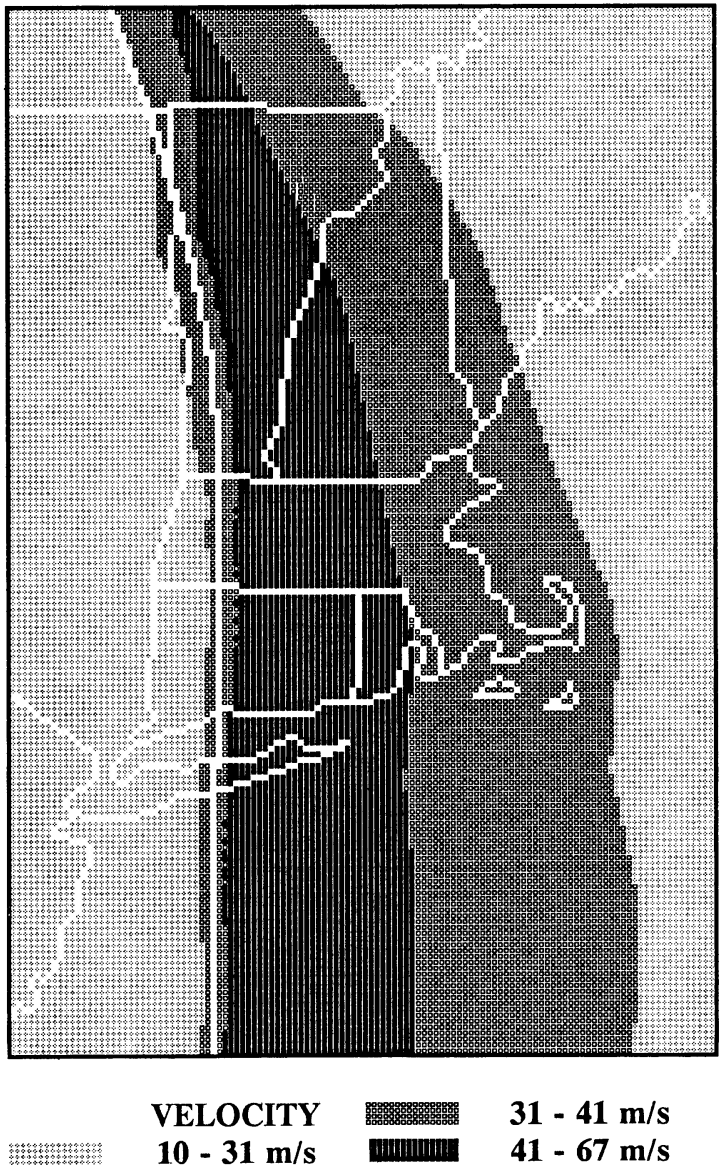

FIG. 21. Forest damage and predicted winds across New England during the 1938 Hurricane. (a) Volume of timber blown down on a town-by-town basis, compiled by the Northeastern Timber Salvage Administration after the storm (NETSA 1943); $10^{6}$ board feet $=2400 \mathrm{~m}^{3}$. (b) Predicted maximum wind gust velocity (adapted from Fig. 20c).

several reasons: (1) Hurricanes require warm ocean water as their primary energy source and normally weaken over the colder oceans of temperate regions (Simpson and Riehl 1981). (2) The Coriolis force increases with latitude, so that the same pressure gradient produces a lower wind speed at higher latitudes (Byers 1974). (3) In temperate regions hurricanes are often influenced by cool, dry air masses that convert the storm's internal dynamics to those of an extratropical storm. While this process may cause short-term intensification, in the long run it reduces maximum wind speed (Byers 1974, Anthes 1982).

Hurricanes in temperate regions tend to move forward at greater speed than those in the tropics, creating a greater asymmetry in the surface wind field (Simpson and Riehl 1981). This contrast was especially clear in the observed and modeled winds for Hurricane Hugo and the 1938 Hurricane, with forward speeds of $5 \mathrm{~m} / \mathrm{s}$ and $25 \mathrm{~m} / \mathrm{s}$ (respectively) upon landfall. In a faster moving storm the highest winds tend to be concen- trated on one side of the storm track, reducing the area of potential destruction and limiting the range of damaging wind directions.

Large-scale geography (e.g., the locations of coastlines and mountain ranges) determines how much a hurricane will be affected by land before it reaches a particular site along a given storm track. Hurricanes weaken over land because of the loss of latent and sensible heat from the ocean surface and because of

TABle 8. Predicted peak winds in the 1938 New England Hurricane at Harvard Forest (Massachusetts) and Pisgah Forest (New Hampshire).

\begin{tabular}{lcccc}
\hline \hline \multicolumn{1}{c}{ Site } & $\begin{array}{c}\text { Time } \\
\text { of day } \\
(\text { EST) }\end{array}$ & $\begin{array}{c}\text { Wind } \\
\text { direction } \\
\left({ }^{\circ}\right)\end{array}$ & $\begin{array}{c}\text { Sustained } \\
\text { velocity } \\
(\mathrm{m} / \mathrm{s})\end{array}$ & $\begin{array}{c}\text { Gust } \\
\text { velocity } \\
(\mathrm{m} / \mathrm{s})\end{array}$ \\
\hline Harvard Forest & 1715 & 135 & 37 & 52 \\
Pisgah Forest & 1730 & 116 & 40 & 57 \\
Pisgah Forest & 1755 & 157 & 40 & 56 \\
\hline
\end{tabular}



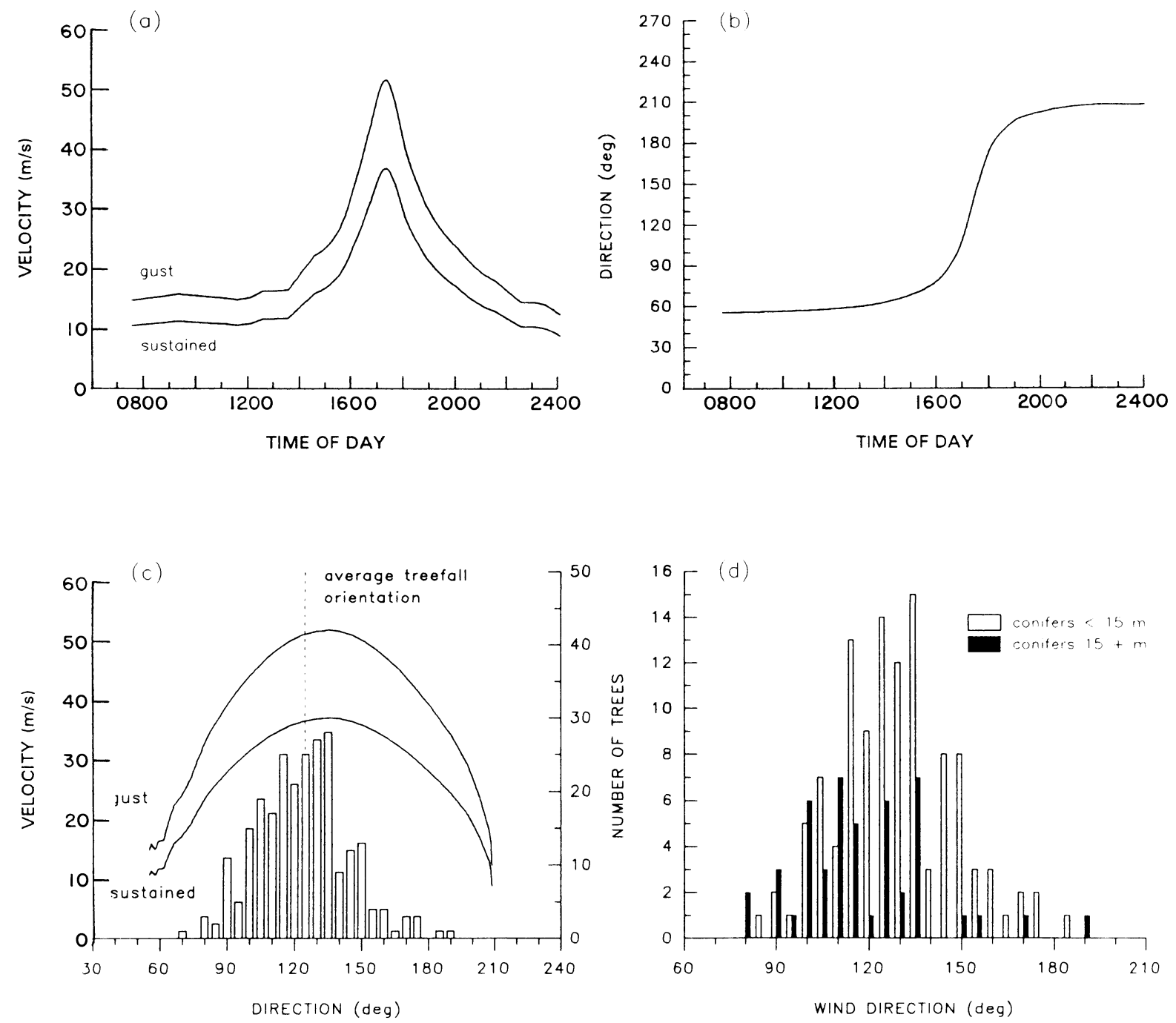

FIG. 22. Treefall orientation and predicted wind at the Harvard Forest (Massachusetts) during the 1938 New England Hurricane. (a) Predicted wind velocity and (b) predicted wind direction as a function of time of day (EST). (c) Lines indicate predicted wind velocity as a function of wind direction. Bars indicate number of wind-thrown trees in $5^{\circ}$ classes as a function of wind direction (Rowlands 1941). (d) Number of wind-thrown conifers in $5^{\circ}$ classes as a function of wind direction. Conifers from stands $<15 \mathrm{~m}$ in height and conifers from stands $\geq 15 \mathrm{~m}$ in height are shown separately.

greater surface friction (Anthes 1982). Mountains can cause considerable distortion of the surface center and rapid weakening within a few hours, though circulation aloft decreases more slowly and many storms regain strength after moving out to sea again (Dunn and Miller 1964), as Hugo did after it passed over Puerto Rico.

These factors help to explain why Puerto Rico experiences more frequent, more intense, and longer lasting hurricanes than New England (Neumann et al. 1987). Historical data show that the range of approach directions for Puerto Rico is less limited (northeast to southeast) than it is for New England, where coastlines and meteorological factors limit severe hurricanes to those that approach from the south. In New England, fewer possible pathways and greater forward speed mean that the direction of damaging winds is more constrained: catastrophic winds should be confined in most cases to the southeast quadrant, as in 1938. Highest wind speeds should occur near the coast, before the hurricane is weakened by landfall. In Puerto Rico the close proximity of large mountains to the coast may cause hurricanes that pass over the island to weaken, as Hugo did, creating a general east-to-west gradient of maximum wind speed.

\section{Regional scale}

The hurricane itself extends across a regional scale $(\approx 500 \mathrm{~km})$ : while the radius of the storm may be as large as $1000 \mathrm{~km}$, the radius of sustained hurricaneforce winds is normally $<100 \mathrm{~km}$. The highest winds 

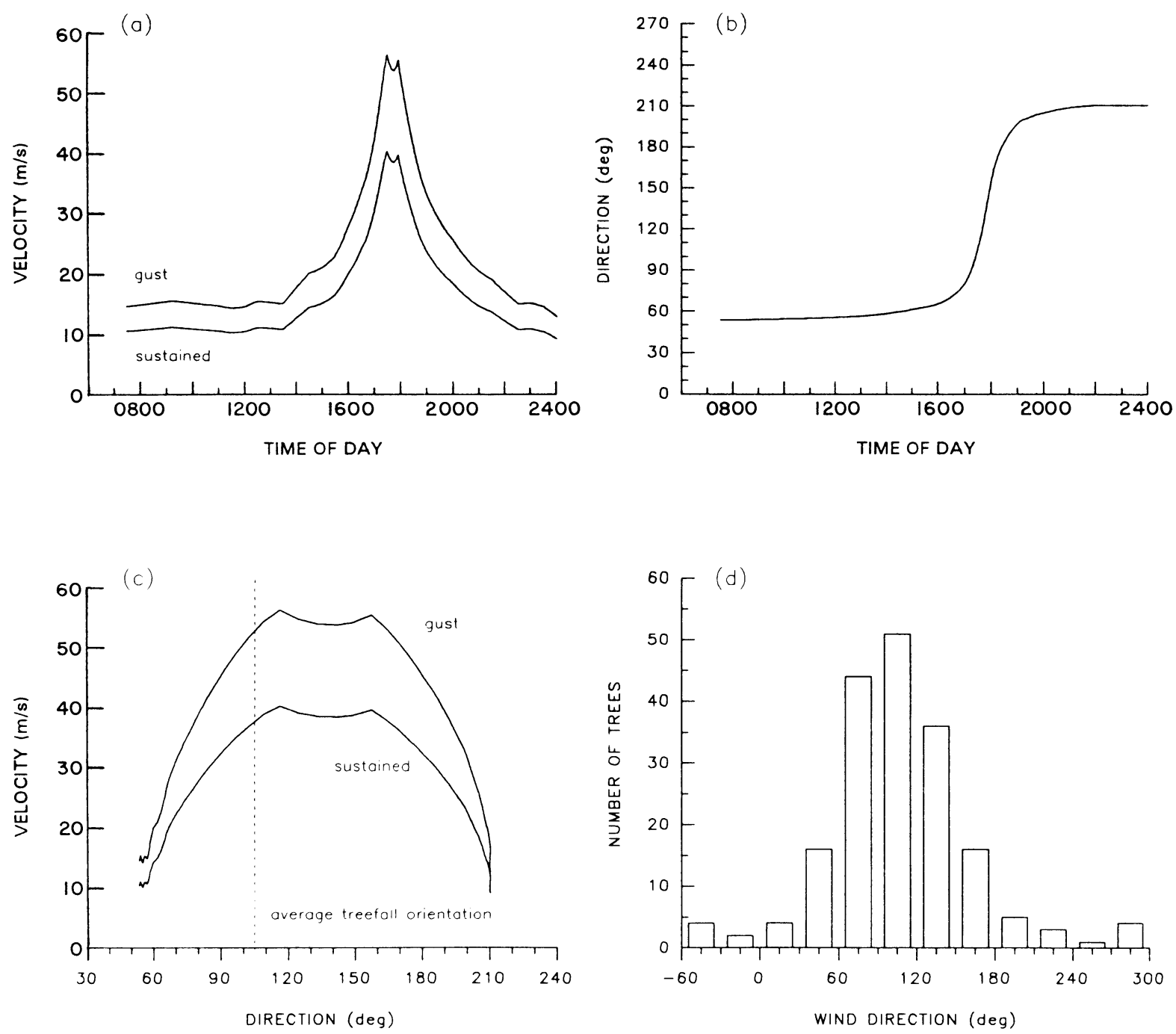

FIG. 23. Treefall orientation and predicted wind at the Pisgah Forest (New Hampshire) during the 1938 New England Hurricane. (a) Predicted wind velocity and (b) predicted wind direction as a function of time of day (EST $=$ Eastern Standard Time). (c) Lines indicate predicted wind velocity as a function of wind direction. Dotted line indicates average treefall orientation. (d) Number of wind-thrown trees in $30^{\circ}$ classes as a function of wind direction (Foster 1988b).

are typically found $\approx 30 \mathrm{~km}$ from the center (the distance may vary from 10 to $80 \mathrm{~km}$ ) and may be confined to a narrow ring of 1-2 km width around the edge of the eye (Simpson and Riehl 1981). The HURRECON model and most models of hurricane structure and dynamics operate at this scale.

The location of coastlines, hills or mountains, and the storm track determines (along with atmospheric and oceanic conditions) how a particular storm will be changed by landfall and how rapidly it will weaken over land. These changes are very complex and not yet fully understood. In our simple model they are approximated as follows: (1) the effects of greater surface friction over land are estimated by reducing sustained wind speeds and increasing the inflow angle for a given central pressure, and (2) the weakening effects of land- fall (including passing over mountains) are estimated by using meteorological observations to calculate the reduction in maximum surface wind speed. As a hurricane finally expires, the ring of maximum winds typically expands outward, the surface wind field changes to that of a tropical storm or an extratropical low, and wind speeds fall below damaging levels (Anthes 1982). At this point the model is no longer applicable.

Factors controlling forest damage at this scale include: (1) broad-scale wind velocity gradients resulting from hurricane size and intensity and proximity to the storm track, (2) broad-scale wind shielding by large topographic features such as mountain ranges, and (3) broad-scale vegetation zones reflecting differences in geology, climate, and disturbance history.

The two hurricanes studied provide interesting con- 


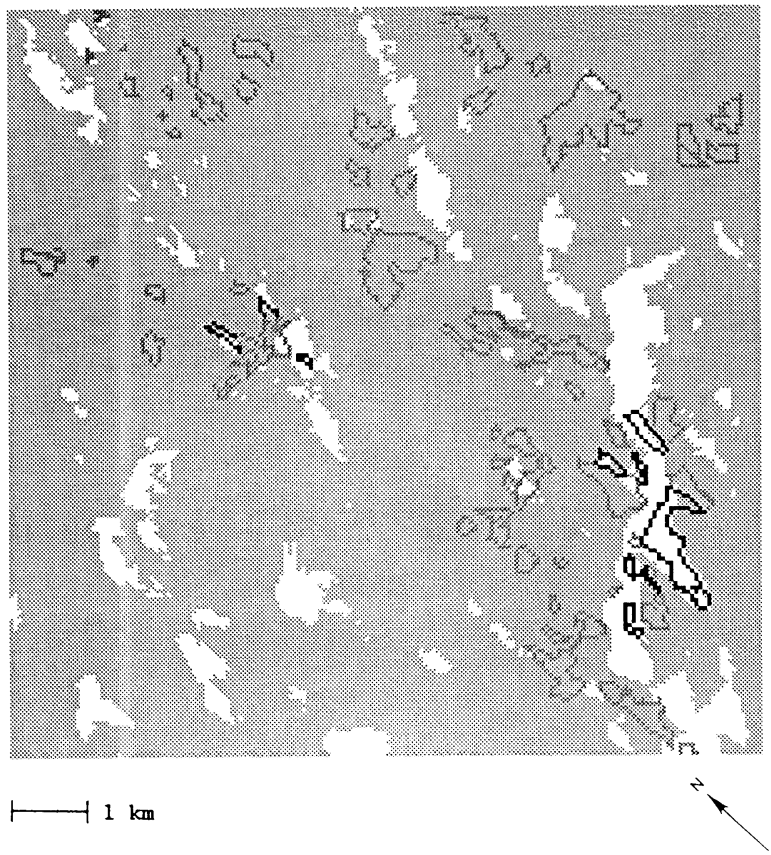

FIG. 24. Damage to mature white pine stands ( $>30 \mathrm{yr}$ old) and predicted exposure in the town of Petersham, Massachusetts, during the 1938 New England Hurricane. Map shows predicted protected areas (white) and exposed areas (grey) for a wind direction of $135^{\circ}$ and inflection angle (downward curvature of airflow path) of $6^{\circ}$. Mature white pine stands that were either undamaged (black outline) or destroyed (grey outline) are also shown.

trasts in these regional factors: in the 1938 Hurricane predicted peak wind velocity and actual damage gradients were nearly parallel to the storm track, while in Hugo they were more nearly perpendicular, because of the slower forward velocity of the storm and more rapid rate of weakening upon landfall. As predicted, broad areas in the lee slopes of the Luquillo Mountains were shielded from the most destructive winds and suffered relatively little damage. At Luquillo the dwarf forests at high elevations appeared to be more resilient to wind damage than lower elevation forests, while the abundance of old-field white pine apparently contributed to the catastrophic effect of the 1938 storm in central New England.

\section{Landscape scale}

Variations in wind conditions at the landscape scale $(\approx 10 \mathrm{~km})$ are greatest in the vicinity of the eyewall (for definition see Methods: Meteorological model (HURRECON): Modeling hurricane winds, above) and in the vicinity of intense convective cells and tornadoes (if they occur) in other parts of the hurricane. Significant variation may also be created by abrupt changes in surface friction (e.g., along coastlines) or by local topography. At this scale HURRECON indicates the general gradient of sustained wind velocity and direction.

Topographic effects at this scale are very complex and may include acceleration of the wind over ridges and summits with strong turbulence on the lee sides, wind channelling up valleys and around protuberances, and variations in exposure due to wind shadowing (Gloyne 1968, Hutte 1968). The last is roughly approximated by EXPOS. Upper mountain slopes exposed to the wind may be affected by the higher velocities normally occurring in a hurricane at higher altitudes.

Factors controlling forest damage at the landscape scale include: (1) wind velocity gradients resulting from hurricane size and intensity and proximity to the storm track, complicated by local convective-scale effects, (2) variation in site exposure and other effects of local topography, and (3) differential response of individual stands to wind disturbance as a function of species composition and structure.

The Northern LEF study area and the town of Petersham (study areas of comparable size) showed interesting contrasts in predicted wind velocity and exposure and in actual forest damage. The strong east-to-west gradient in actual damage across the Northern LEF study area paralleled the predicted gradient in peak wind speed (a result of proximity to the storm track and significant weakening during the storm's passage), while linear patterns of extreme damage in the east section appeared to be caused by intense convective cells before the storm weakened. No broad-scale damage gradient was observed across Petersham, nor was any significant difference predicted in peak wind speed (a result of greater distance from the storm track and little weakening during the storm's passage). In the steep mountain terrain of the Northern LEF study area there were relatively large areas that sustained little damage, while

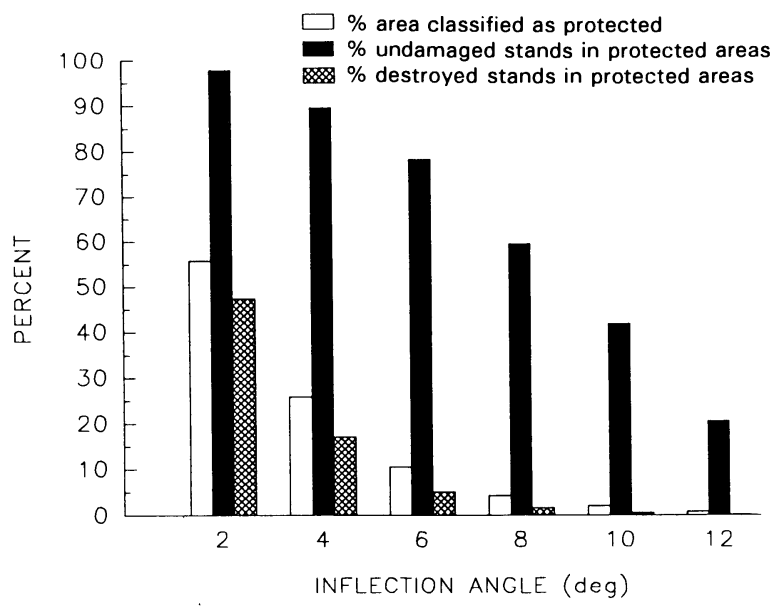

FIG. 25. Damage to mature white pine stands ( $>30 \mathrm{yr}$ old) and predicted exposure for different inflection angles in the town of Petersham, Massachusetts, during the 1938 New England Hurricane. Wind direction $=135^{\circ}$. 


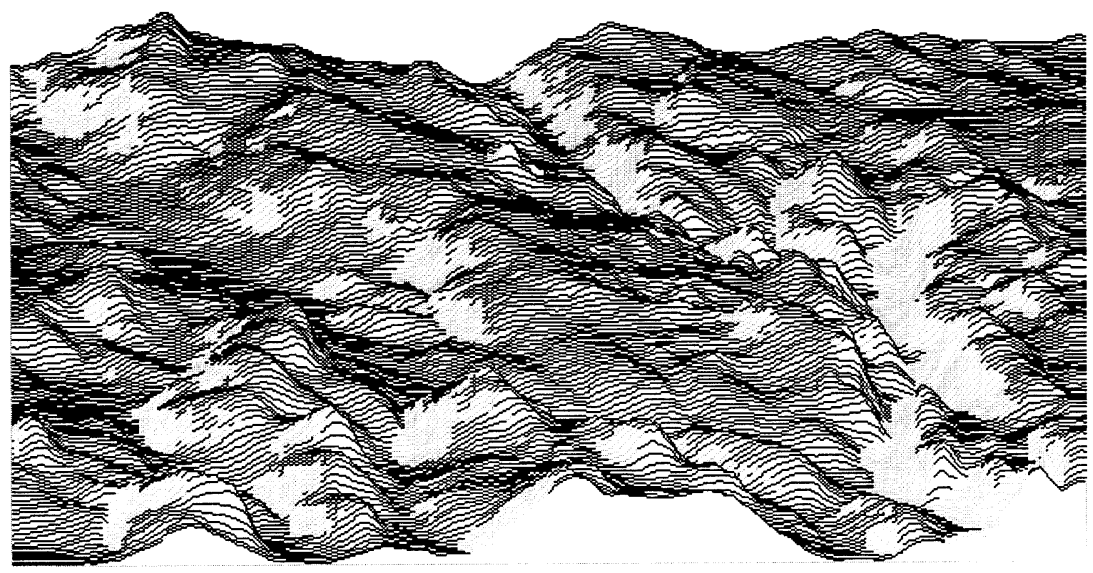

Fig. 26. Predicted exposure in the town of Petersham, Massachusetts (light $=$ protected, dark $=$ exposed). The view is toward the northeast. Wind direction $=135^{\circ}$; inflection angle $=6^{\circ}$.

in the gently rolling terrain of Petersham damage was more widespread; in both cases damage patterns matched predicted exposure fairly well.

\section{Stand scale}

Variations in wind conditions at the stand scale $(\approx 1$ $\mathrm{km})$ are largely due to individual wind gusts created by turbulent eddies, and wind gradients associated with intense convective cells and tornadoes. These effects cannot be predicted by HURRECON. Changes in wind flow may result from small-scale topographic features and from the structure of the forest itself.

Details of the damage patterns at this scale often reveal exceptions to the general patterns: e.g., small patches of dissimilar damage in broader homogeneous areas or local windthrow patterns that do not match the overall trends. These details are highly relevant to community-level studies, despite their minor areal extent. Causative factors appear to include: (1) local wind gusts and convective-scale effects, (2) in rugged terrain, variation in site exposure and other topographic effects, and (3) variation in species susceptibility to wind damage. Factors contributing to the last may include overall morphology, age, size, form, health, and rooting conditions.

Patterns of treefall orientation in the two hurricanes studied pointed to interesting differences in the degree of local topographic control of wind direction. The HURRECON model predicted little variation in the direction of the peak sustained wind in the LEF (because of proximity to the storm track), but a wide range in treefall orientation was observed, suggesting considerable air turbulence and variation in wind gust direction (apparently caused by the rugged terrain). In addition, analysis of the tree orientation vectors suggested that the primary air flow was deflected or channelled at times by local topographic features. At the Harvard and Pisgah Forests a much wider range of high wind directions was predicted (because of distance from the storm track), but the actual range in treefall orientation was much narrower than in the LEF, suggesting that turbulence and topographic control were less important in the gentler terrain of central New England.

\section{Conclusion}

The patterns of damage resulting from hurricane impact on a forested landscape are a result of the interaction of meteorological, physiographic, and biotic factors. This interaction can be investigated on a series of spatial scales by combining models that estimate meteorological and topographic effects with damage assessment through analysis of remotely sensed, historical, and field data. This approach may be used to study the effects of local topography on wind direction and the relation of forest damage to wind speed and duration. It may be combined with historical data to reconstruct long-term hurricane disturbance regimes or with global climate model predictions to estimate future hurricane impacts, at both regional and landscape scales.

\section{ACKNOWLEDGMENTS}

This study benefited greatly from discussions with C. Cogbill, B. Hayden, A. Lugo, F. Scatena, F. Swanson, and H. Willoughby, and from comments on the manuscript by $\mathrm{R}$. Waide. The authors thank B. Hayden for insights on the physics of wind and vegetation, $\mathrm{H}$. Willoughby for providing aircraft observations of Hurricane Hugo, R. Waide for logistical support in Puerto Rico, E. Everham for help in obtaining the El Verde treefall data, and E. Moriarty and C. Whiting for assistance in preparing the figures. The research was supported by the National Science Foundation and is a contribution from the Harvard Forest and Luquillo Long-Term Ecological Research Programs.

\section{LITERATURE Cited}

Anthes, R. A. 1982. Tropical cyclones: their evolution, structure and effects. Meteorological Monographs 19 (41). American Meteorological Society, Boston, Massachusetts, USA.

Atkinson, G. D., and C. R. Holliday. 1977. Tropical cyclone 
minimum sea level pressure/maximum sustained wind relationship for the Western North Pacific. Monthly Weather Review 105:421-427.

Baldwin, H. 1942. Forestry in New England. Publication Number 70. National Resources Planning Board, Region One, Boston, Massachusetts, USA.

Bates, C. G. 1930. Hurricane damage to Porto Rican forests. Journal of Forestry 28:772-774.

Bormann, F. H., and G. E. Likens. 1979. Pattern and process in a forested ecosystem. Springer-Verlag, New York, New York, USA.

Boucher, D. H., J. H. Vandermeer, K. Yih, and N. Zamora. 1990. Contrasting hurricane damage in tropical rain forest and pine forest. Ecology 71:2022-2024.

Briscoe, C. B. 1966. Weather in the Luquillo Mountains of Puerto Rico. U.S. Forest Service Research Paper ITF-3.

Brooks, C. F. 1940. Hurricanes into New England: meteorology of the storm of September 21, 1938. Pages 241251 in Smithsonian Institution Report 3563. United States Government Printing Office, Washington, D.C., USA.

Brown, S., A. E. Lugo, S. Silander, and L. Liegel. 1983. Research history and opportunities in the Luquillo Experimental Forest. U.S. Department of Agriculture General Technical Report SO-44.

Byers, H. R. 1974. General meteorology. Fourth edition. McGraw-Hill, New York, New York, USA.

Churchill, S. W. 1988. Viscous flows: the practical use of theory. Butterworths, Boston, Massachusetts, USA.

Cole, L. C. 1949. The measurement of interspecific association. Ecology 30:41 1-424.

Crow, T. R. 1980. A rainforest chronicle: a 30-year record of change in structure and composition at El Verde, Puerto Rico. Biotropica 12:42-55.

Crow, T. R., and D. F. Grigal. 1980. A numerical analysis of arborescent communities in the rain forests of the Luquillo Mountains, Puerto Rico. Vegetatio 40:135-146.

Darling, N. 1842. Notice of a hurricane that passed over New England in September, 1815. American Journal of Science and Arts 42:243-252.

Denslow, J. S. 1985. Disturbance-mediated coexistence of species. Pages 307-323 in S. T. A. Pickett and P. S. White, editors. The ecology of natural disturbance and patch dynamics. Academic Press, New York, New York, USA.

Doyle, T. W. 1981. The role of disturbance in the gap dynamics of a montane rain forest: an application of a tropical forest succession model. Pages 56-73 in D. C. West, H. H. Shugart, and D. Botkin, editors. Forest succession: concepts and application. Springer-Verlag, New York, New York, USA.

Dunn, G. E., and B. I. Miller. 1964. Atlantic hurricanes. Revised edition. Louisiana State University Press, Baton Rouge, Louisiana, USA.

Emanuel, K. A. 1987. The dependence of hurricane intensity on climate. Nature 326:483-485.

Ewel, J. J., and J. L. Whitmore. 1973. Ecological life zones of Puerto Rico and the U.S. Virgin Islands. USDA Forest Service Research Paper ITF-18.

Fletcher, R. D. 1955. Computation of maximum surface winds in hurricanes. Bulletin of the American Meteorological Society 36:247-250.

Foster, D. R. 1988a. Disturbance history, community organization and vegetation dynamics of the old-growth Pisgah Forest, south-western New Hampshire, U.S.A. Journal of Ecology 76:105-134.

- $1988 \mathrm{~b}$. Species and stand response to catastrophic wind in central New England, U.S.A. Journal of Ecology 76:135-151.

Foster, D. R., and E. R. Boose. 1992. Patterns of forest damage resulting from catastrophic wind in central New England, U.S.A. Journal of Ecology 80:79-98.
Frank, W. M. 1977. The structure and energetics of the tropical cyclone: I. Storm structure. Monthly Weather Review 105:1119-1135.

Fujita, T. T. 1971. Proposed characterization of tornadoes and hurricanes by area and intensity. Satellite and Mesometeorology Research Project Paper 91. Department of Geophysical Sciences, University of Chicago, Chicago, Illinois, USA.

Gentry, R. C. 1966. Nature and scope of hurricane damage. American Society for Oceanography Publication 1:229-241.

Gifford, J. C. 1905. The Luquillo Forest Reserve, Porto Rico. U.S. Department of Agriculture Bureau of Forestry Bulletin Number 54.

Gloyne, R. W. 1968. The structure of the wind and its relevance to forestry. Forestry 41:7-19.

Gould, E. M. 1960. Fifty years of management at the Harvard Forest. Harvard Forest Bulletin 29.

Holdridge, L. R. 1946. A brief sketch of the Puerto Rican flora. Pages 81-83 in F. Verdoorn, editor. Plants and plant science in Latin America. Chronica Botanica, Waltham, Massachusetts, USA.

Howard, R. A. 1968. The ecology of an elfin forest in Puerto Rico. 1. Introduction and composition studies. Journal of the Arnold Arboretum 49:381-418.

Hutte, P. 1968. Experiments in windflow and wind damage in Germany; site and susceptibility of spruce forests to storm damage. Forestry 41:20-26.

Lawrence, M. 1989. Preliminary report: Hurricane Hugo, 10-22 September 1989. National Hurricane Center, Coral Gables, Florida, USA.

Ludlum, D. M. 1963. Early American hurricanes 14921870. American Meteorological Society, Boston, Massachusetts, USA.

Lugo, A. E., M. Applefield, D. Pool, and R. McDonald. 1983. The impact of Hurricane David on the forests of Dominica. Canadian Journal of Forest Research 13:201-211.

Lugo, A. E., and F. N. Scatena. 1993. Ecosystem-level properties of the Luquillo Experimental Forest with emphasis on the Tabonuco Forest. Chapter 4 in A. E. Lugo and C. Lowe, editors. A century of tropical forestry research: results from the first half, plans for the second. Elsevier, New York, New York, USA.

Lugo, A. E., and R. B. Waide. 1993. Catastrophic and background disturbance of tropical ecosystems at the Luquillo Experimental Forest. Journal of Bioscience 18:475-481.

Matos, I. 1989. Statement on Hurricane Hugo (revised), Oct. 24, 1989. National Weather Service Forecast Office, San Juan, Puerto Rico.

Millas, J. C. 1968. Hurricanes of the Caribbean and adjacent regions 1492-1800. Academy of the Arts and Sciences of the Americas, Miami, Florida, USA.

Miller, B. I. 1967. Characteristics of hurricanes. Science 157: 1389-1399.

Moore, P. D. 1989. Blow, blow thou winter wind. Nature 336:313.

Naka, K. 1982. Community dynamics of evergreen broadleaf forests in southwestern Japan. I. Wind damaged trees and canopy gaps in evergreen oak forest. Botanical Magazine, Tokyo 95:385-399.

NETSA [Northeast Timber Salvage Administration]. 1943. Report of the U.S. Forest Service programs resulting from the New England Hurricane of September 21, 1938. Northeastern Timber Salvage Administration, Boston, Massachusetts, USA.

Neumann, C. J., B. R. Jarvinen, and A. C. Pike. 1987. Tropical cyclones of the North Atlantic Ocean 1871-1986. Third revised edition. NOAA-National Climatic Data Center, Asheville, North Carolina, USA.

NOAA [National Oceanic and Atmospheric Administration]. 1971. Some devastating North Atlantic hurricanes of the 
20th century. U.S. Government Printing Office, Washington, D.C., USA.

1989. Hurricane Hugo, September 10-22, 1989. Storm data 31:11-27.

O'Brien, S. T., B. P. Hayden, and H. H. Shugart. 1992. Global climate change, hurricanes, and a tropical forest. Climate Change 22:175-190.

Perley, S. 1891. Historic storms of New England. Salem Press, Salem, Massachusetts, USA.

Pierce, C. H. 1939. The meteorological history of the New England Hurricane of Sept. 21, 1938. Monthly Weather Review 67:237-285.

Powell, M. D. 1982. The transition of the Hurricane Frederic boundary-layer wind field from the open Gulf of Mexico to landfall. Monthly Weather Review 110:1912-1932.

- 1987. Changes in the low-level kinematic and thermodynamic structure of Hurricane Alicia (1983) at landfall. Monthly Weather Review 115:75-99.

Rowlands, W. 1941. Damage to even-aged stands in Petersham, Massachusetts by the 1938 Hurricane as influenced by stand condition. Thesis. Harvard University, Cambridge, Massachusetts, USA.

Salivia, L. A. 1950. Historia de los temporales de Puerto Rico. Editorial Edil, San Juan, Puerto Rico.

Scatena, F. N., and M. C. Larsen. 1991. Physical aspects of Hurricane Hugo in Puerto Rico. Biotropica 23:317-323.

Shapiro, A. H. 1961. Shape and flow: the fluid dynamics of drag. Doubleday, New York, New York, USA.

Shaw, W. B. 1983. Tropical cyclones: determinants of pattern and structure in New Zealand's indigenous forests. Pacific Science 37:405-414.

Simpson, R. H., and H. Riehl. 1981. The hurricane and its impact. Louisiana State University Press, Baton Rouge, Louisiana, USA.

Smith, D. M. 1946. Storm damage in New England forests. Thesis. Yale University, New Haven, Connecticut, USA.
Stephens, E. P. 1955. The historical-development method of determining forest trends. Dissertation. Harvard University, Cambridge, Massachusetts, USA.

Tannehill, I. R. 1938. Hurricane of September 16 to 22, 1938. Monthly Weather Review 66:286-288.

Vogel, S. 1993. When leaves save the tree. Natural History 102(9):58-62.

Wadsworth, F. H. 1970. Review of past research in the Luquillo Mountains of Puerto Rico. Pages B-33-B-46 in H. T. Odum and R. F. Pigeon, editors. A tropical rain forest. U.S. Atomic Energy Commission, Washington, D.C., USA.

Waide, R. B., and A. E. Lugo. 1992. A research perspective on disturbance and recovery in a tropical montane forest. Pages 173-190 in J. G. Goldammer, editor. Tropical forests in transition. Birkhauser Verlag, Basel, Switzerland.

Walker, L. R., D. J. Lodge, N. V. L. Brokaw, and R. B. Waide, editors. 1991. Ecosystem, plant, and animal responses to hurricanes in the Caribbean. Biotropica 23.

Weaver, P. L. 1986. Hurricane damage and recovery in the montane forests of the Luquillo mountains of Puerto Rico. Caribbean Journal of Science 22:53-70.

- 1987. Structure and dynamics in the Colorado Forest of the Luquillo Mountains of Puerto Rico. Dissertation. Michigan State University, East Lansing, Michigan, USA.

Webb, L. J. 1958. Cyclones as an ecological factor in tropical lowland forest, North Queensland. Australian Journal of Botany 6:220-228.

Westveld, M. 1956. Natural forest vegetation zones of New England. Journal of Forestry 54:332-338.

Whigham, D., I. Olmstead, E. Cano, and M. Harmon. 1991. The impact of Hurricane Gilbert on trees, litterfall, and woody debris in a dry tropical forest in Northeastern Yucatan Peninsula. Biotropica 23:434-441.

Whitaker, S. 1968. Introduction to fluid mechanics. Prentice-Hall, Englewood Cliffs, New Jersey, USA.

\section{APPENDIX}

\section{DETAILS OF THE HURRECON MODEL}

Characteristics of the hurricane's surface wind field and assumptions underlying the model equations are discussed below.

Assumption 1: The hurricane eye (see Methods: Meteorological model (HURRECON): Modeling hurricane winds) and the surrounding isobars are circular. Discussion: The eye may be slightly elliptical. In such cases the model approximates the eye as a circle whose diameter is the average of the major and minor axes of the ellipse. Isobars within the radius of damaging winds (the area of interest) are very nearly circular in most hurricanes (Simpson and Riehl 1981).

Assumption 2: The surface wind field is asymmetrical, with the highest sustained wind speeds in the eyewall (see Methods: Meteorological model (HURRECON): Modeling hurricane winds) occurring on the right side of the eye and the lowest wind speeds on the left side. The difference between the two is twice the forward velocity of the storm. Sustained wind velocity in the eyewall $(V e)$ is estimated as:

$$
V_{e}=V_{m}-V_{h}(1-\sin A),
$$

where $V_{m}=$ maximum sustained wind velocity at any location if the hurricane were entirely over water, $V_{h}=$ forward velocity of hurricane, and $A=$ clockwise angle between forward path of hurricane and a radial line to a point $P$. This yields $V_{e}=V_{m}$ at $A=90^{\circ}, V_{e}=V_{m}-V_{h}$ at $A=0^{\circ}$ or $180^{\circ}$, and $V_{e}$ $=V_{m}-2 V_{h}$ at $A=270^{\circ}$. Discussion: Maximum wind speed normally occurs on the right side of the storm approximately at right angles to the forward path. The difference between the left and right wind speeds in the eyewall is normally about twice the forward velocity of the storm (Simpson and Riehl 1981).

Assumption 3: The sustained wind velocity $(V s)$ at a point $P$ on a radial line beginning at the hurricane center can be approximated as follows:

$$
\begin{array}{ll}
V_{s}=V_{e}\left(R / R_{e}\right) & \text { inside the eye } \\
V_{s}=V_{e}\left(R_{e} / R\right)^{X} & \text { outside the eye, }
\end{array}
$$

where $V_{e}=$ sustained wind velocity in the eyewall on the radial line, $R=$ radial distance from hurricane center to point $P, R_{e}=$ radius of eye, and $X=$ a constant between 0.4 and 0.8 . Discussion: These are standard equations for estimating the tangential wind velocity of a hurricane (Miller 1967, Simpson and Riehl 1981, Anthes 1982). Since the model assumes the inflow angle to be constant for a given surface type (land or water; see Assumption 8, below), the total wind speed is proportional to the tangential wind speed over that surface type. The value of $X$ is related to the size of the storm and determines how rapidly the modeled winds decrease as one moves away from the center. Note that Eq. 1 follows directly from Eqs. A.1 and A.2 plus the friction factor discussed below (see Assumption 5).

Assumption 4: The wind profile constant $X$ remains constant over the period of interest (normally $\approx 24 \mathrm{~h}$ for one site). Discussion: Values of $X$ for Hurricane Hugo and the 1938 Hurricane were determined from wind observations at a single 
station during passage of the storm. A single station provides a transect of the hurricane over both space and time, and so gives a rough measure of $X$ over time if the storm does not intensify or weaken rapidly.

Assumption 5: During and after landfall, sustained wind velocities over land are a fixed fraction of what they would have been (in the same part of the storm and at the same time) over water. Discussion: The actual reduction in wind speed over land due to friction varies as a function of surface roughness, fetch, and initial wind speed. A fixed value for the reduction in sustained wind velocity due to friction, $F$, of 0.8 , determined from empirical studies at coastal stations (Powell 1982), was used in this paper.

Assumption 6: The peak wind gust velocity $\left(V_{g}\right)$ equals the sustained wind velocity $\left(V_{s}\right)$ times a fixed wind gust factor $(G)$ for a given surface type (land or water). Discussion: Surface wind gusts are caused by turbulent eddies in which momentum is transported downward from higher velocity winds aloft. Highest wind speeds normally occur at an altitude of 500 $1500 \mathrm{~m}$ above the surface; at this height there is little difference in wind speeds over water and over land (Powell 1982). The surface gust factor increases with surface roughness (Simpson and Riehl 1981) and decreases with height above the ground and with increasing wind speed (Atkinson and Holliday 1977). Although sustained wind speeds over land are slower than over water, peak gust speeds are roughly the same (Atkinson and Holliday 1977). In this paper we used typical gust factors ( $10 \mathrm{~m}$ above ground level) of $G=1.4$ over land (Powell 1982) and 1.12 over water (Atkinson and Holliday 1977), yielding identical gust speeds over land and water.

Assumption 7: The direction of peak wind gusts $\left(D_{g}\right)$ is the same as the direction of the sustained wind $\left(D_{s}\right)$. Discussion:
In fact the direction of wind gusts may vary to either side of the sustained wind direction. However this variation is reported to be minimal in hurricanes because of the nature of the turbulent eddies involved (Simpson and Riehl 1981).

Assumption 8: The cross-isobar inflow angle $(I)$ is everywhere constant over a given surface type (land or water). The estimated wind direction is thus set to the counterclockwise tangent minus the inflow angle. Discussion: In fact the inflow angle varies with surface roughness, storm quadrant, storm velocity, storm intensity, storm maturity, latitude, and environmental flow (Dunn and Miller 1964, Simpson and Riehl 1981). The most important factor is surface roughness, since surface friction reduces air velocity, thereby reducing the outward centrifugal and Coriolis forces that act on the air. Because the inward pressure gradient force is not reduced, the result is an inward spiral of air at surface levels (Simpson and Riehl 1981). Values for the mean inflow angle reported in the literature include $23^{\circ}$ over water and $38^{\circ}$ over land (Dunn and Miller 1964), $16^{\circ}$ for ships at sea and $20-25^{\circ}$ for small islands (Frank 1977), and $15-20^{\circ}$ (moderate hurricane) up to $20-40^{\circ}$ (severe hurricane) over water plus an additional $10-30^{\circ}$ over land (Simpson and Riehl 1981). Intermediate values of $20^{\circ}$ over water and $40^{\circ}$ over land were used in this paper.

Assumption 9: Wind velocity and direction can be estimated as above, even for points distant from the hurricane center. Discussion: In fact the model equations apply only within a few hundred kilometres of the hurricane center. This distance is a function of the size of the particular storm and the surrounding meteorological conditions. Model estimates appear to be reliable within the radius of gale-force winds - the area of interest for studying forest damage. 